Received 12 April 2020, Accepted 20 April 2020

\title{
Designing Fascism: The evolution of a neo-nazi punk aesthetic
}

Ana Raposo, ESAD and Russ Bestley, London College of Communication

\section{Biographies}

\section{Ana Raposo}

Ana Raposo is a graphic designer, educator and design researcher. She completed her PhD entitled 30 Years of Agitprop: The Representation of 'Extreme' Politics in Punk and Post-Punk Music Graphics in the United Kingdom from 1978 to 2008 at Central Saint Martins, London in 2013. Her publications include chapters in Where Have All the Bootboys Gone? (2013), The Aesthetic of Our Anger (2016) and Tomorrow Belongs to Us (2017). Ana is a lecturer on the Masters in Communication Design programme at ESAD College of Art and Design, Porto, and a member of ESAD-IDEA, the editorial board of Punk \& Post-Punk and the Punk Scholars Network.

Contact: ESAD, Avenida Calouste Gulbenkian, 4460-268 Senhora da Hora, Matosinhos, Portugal E-mail: anaraposo@esad.pt

ORCID: https://orcid.org/0000-0002-4129-2164

\section{Russ Bestley}

Russ Bestley is a designer and writer, specialising in graphic design, punk and humour. His publications include A Different Kind of Tension: Post-Punk Graphic Design in the UK, 19761990 (forthcoming), Action Time Vision (2016), The Art of Punk (2012), Visual Research (2004, 2011, 2015, forthcoming) and Up Against the Wall (2002). Russ is Reader in Graphic Design \& Subcultures at the London College of Communication, editor of the journal Punk \& Post-Punk and co-editor of the Global Punk book series published by Intellect Books and the Punk Scholars Network. His research archive can be accessed at www.hitsvilleuk.com.

Contact: School of Design, London College of Communication, University of the Arts London, Elephant \& Castle, London SE1 6SB

E-mail: r.bestley@lcc.arts.ac.uk 


\begin{abstract}
This article explores the design strategies of four record labels associated with the growth of an explicitly far right sub-genre of punk in the United Kingdom between 1979 and the early 2000s: Rock-O-Rama Records, White Noise Records, Rebelles Européens and ISD Records. While Rock-ORama saw the inclusion of the genre as simply an extension of their existing business model, the other labels featured were established specifically to support the activities of a small number of explicitly far right groups who were blacklisted by mainstream producers and distributors within the music industry. These labels were also able to develop independent, do-it-yourself approaches to marketing, promotion and distribution that bear striking similarity to other sub-genres of punk and post-punk in the United Kingdom and Europe, particularly the politically activist hardcore and anarcho-punk scenes.
\end{abstract}

Earlier examples of record covers that employed ambiguous visual metaphors to evoke a mythical Aryan identity were eventually superseded by the emergence of a more extreme form of visual communication that utilized overtly racist images alongside symbols with specific coded meanings to demonstrate a commitment to the white nationalist cause. These visual strategies were to become more explicit as far right punk scenes moved to embrace fascist ideologies in the 1990s and beyond, as connotations of brotherhood, persecution, endurance, Norse mythology and the nation eventually gave way to direct calls-to-arms and pledges of allegiance with White Power and neo-nazi terrorist groups.

The association between punk scenes and far right politics, ${ }^{1}$ particularly in the late 1970 s and 1980s, has been documented by a number of authors (Hebdige 1982; Sabin 1999; Cotter 1999; Forbes \& Stampton 2015; Raposo and Sabin 2017; Copsey and Worley 2017; Worley 2017), together with the internecine rivalries, ideological fall-outs and subsequent splits between various factions of nationalist and neo-nazi groups and associated political parties (Lowles 2001; Lowles and Silver 1998; Copsey and Worley 2017; Shaffer 2017). Equally, the evolution of a skinhead punk scene largely centred around the Oi! movement (latterly termed street punk) along with its dress styles, aesthetics and problematic public image has featured in a number of punk histories (Knight 1982; Worley 2012, 2014, 2017; Vague 2013; Bestley 2013; Weiner 2018). This article draws on this critical context but does not seek to repeat it, focusing instead on the use of imagery and visual devices as a tool for propaganda and the evolution of graphic styles on

\footnotetext{
1 The broad spectrum of far right politics covers neo-fascism, neo-nazism and white supremacism along with a range of other nationalist, racist and authoritarian ideologies. The term far right is used here to describe membership or allegiance to extreme nationalist groups, while specific terms such as neonazism and White Power are used to describe particular elements within that wider field.
} 
the covers of records produced by participants in the developing 'White Power' music scene between 1979 and the late 1990s. Raposo and Sabin (2017) analysed the graphics and other visual material associated with the British far right music scene from 1982-1987 and the ways in which;

punk aesthetics (a DIY approach, spontaneity, and use of collage) meshed with skinhead obsessions (boots, violence, and 'martyr images') and tropes derived from far-right political culture (swastikas, runic symbols, and Aryan ideal body-types) to produce an aesthetic that became a new kind of subcultural language. (Raposo and Sabin 2017: 132)

This article extends that study by looking in-depth at four individual record labels and charting developments beyond 1987 and into the early twenty-first century, including the transition from a purely nationalist political agenda to wider forms of international collaboration. From the late 1980s onward, a more radical shift toward paramilitary and terrorist affiliations took the British White Noise rock and punk scene to an even darker place than before.

\section{Punk and the Far right}

Some early punk groups in the United Kingdom had attracted a broad following which included hooligan, skinhead and right-wing elements. This was a constant problem for groups such as Sham 69 and the Angelic Upstarts, both of which attracted working class fans from across the political spectrum. As Angelic Upstarts singer Mensi later reflected,

To me it seemed like a bit of a right-wing movement in parts. I didn't like the exclusive white working-class thing - I would rather it was just a working-class thing. The right-wing would latch onto every band, and it's not the band's fault. Sometimes they can be very intimidating so bands won't speak out against them. (Robb 2006: 473)

The skinhead revival of the late 1970s, together with a resurgence in support for political parties such as the National Front and the National Party2 (Copsey and Worley 2017; Shaffer 2017; Sabin 1999) or the more street-level British Movement, led to increasing numbers of far right skinheads attending punk gigs and causing trouble with other members of the audience. Far right factions

\footnotetext{
${ }^{2}$ The National Party was founded in December 1975 by John Kingsley-Read following a schism in the leadership of the National Front.
} 
also battled with each other: following a disastrous showing in the May 1979 General Election, the National Front split into a number of rival organisations,

Other smaller groupings existed, among them the League of Saint George, before the NF's disappointing general election performance in 1979 occasioned a round of splits and divisions that threw up the New National Front, the British Democratic Party, the Constitutional Movement and, in 1982, the British National Party (BNP). (Worley and Copsey 2017: 116)

The punk group most commonly associated with far right politics were Skrewdriver, originally formed in Blackpool in 1977 and signed to the London-based Chiswick label - an early independent bridging pub rock and punk. Their early singles, 'You're So Dumb' and 'Anti-Social' (both released in 1977) were classic early examples of what would later become known as street punk. The group were not commercially successful and, following a number of image changes, they split officially in 1979. Lead singer Ian Stuart Donaldson (widely known as Ian Stuart) went on to form a new line up of the group, this time adopting an openly far right political stance in support of the National Front.

Rock Against Communism (RAC) was launched in Leeds in 1979, under the umbrella of the Young National Front, as a direct rebuttal to the widely supported Rock Against Racism campaign. While suspicion, or even antipathy, toward youth subcultures and rock 'n' roll music was widespread among senior figures in the National Front, Copsey and Worley later observed that 'blunt punk rock remained RAC's music of choice' (2017: 124) and attempts were made to draw punk groups and fans to the cause. Eddy Morrison, the Leeds and Yorkshire organiser for the National Front, later reflected on the rationale for getting involved in the developing punk scene,

I could also see that Punk was becoming a powerful weapon for anyone who could turn it politically. The reds were already attempting to do this with their newly formed 'Rock Against Racism', and many teenagers went to their concerts, not because they were anti-racist but simply to hear the music. This couldn't be allowed to continue. We either had to condemn Punk or use it. (Morrison 2002: 15)

The leadership of Rock Against Communism moved from Morrison in Leeds to Joe Pearce in London and eventually led to the formation of the more explicitly ideological White Noise Club in 
collaboration with Ian Stuart's reformed Skrewdriver in 1982. ${ }^{3}$ Widespread opposition to RAC groups and disruption of gigs had by this time driven the scene underground and cemented its outsider status, as the 'inability to access either the major or independent record industry necessitated RAC forge its own labels, media and distribution networks' (Worley and Copsey 2017: 124). In turn, this distillation of the far right skinhead punk scene encouraged leading activists to shift even further toward overtly fascist positions,

Concurrently, all lack of pretence as to working through established media channels led the politics of RAC to become ever more extreme. If 'White Power' (1983) had seen Skrewdriver segue easily from songs of national pride to slogans of racial supremacy, then Blood \& Honour (1985) and White Rider (1987) saw Stuart openly endorse the politics of national socialism. (Worley and Copsey 2017: 125)

A split between Stuart's followers and the National Front in 1987 led to the formation of the Blood \& Honour movement, named after a Skrewdriver song and intended to provide an outlet for far right skinhead music and a network for live gigs and fundraising for neo-fascist political groups. By this time, Stuart and others were drawing directly from the history of the Third Reich,

Now, the visual identity of UK neo-fascist rock became associated less with union flags and nationalist nostalgia, and more with a melding of neo-fascist skinhead culture and Nazi-era symbolism. (Raposo and Sabin 2017: 133)

Such a move reflected wider developments in far right politics and among its supporters within youth subcultures and music scenes,

The neo-fascist wing was no longer content to identify itself as hard-punks-with-anattitude-against-immigrants, but in the early 1980s moved more towards a selfimage that might best be described as street-fighting 'stormtroopers' (as some publications were putting it). (Raposo and Sabin 2017: 134)

This article explores the design strategies of four record labels associated with the growth of an explicitly far right sub-genre of punk in Europe between 1979 and the early 2000s: Rock-O-Rama Records, White Noise Records, Rebelles Européens and ISD Records. While Rock-O-Rama saw the

\footnotetext{
${ }^{3}$ Ryan Shaffer suggests that the White Noise Club was a direct subsidiary organisation of the National Front, under the leadership of Derek Holland and Patrick Harrington. (Shaffer 2017: 117)
} 
inclusion of the genre as simply an extension of their existing business model, a strategy that saw other bands on their roster fall victim to accusations of fascist sympathies through a form of guilt by association, the other labels were established specifically to support the activities of a small number of neo-fascist groups who were blacklisted by mainstream producers and distributors within the music industry. These labels were also able to develop independent, do-it-yourself approaches to marketing, promotion and distribution that bear striking similarity to other subgenres of punk and post-punk in the United Kingdom and Europe, particularly the politically activist hardcore and anarcho-punk scenes. Leading figureheads of what would subsequently become known as anarcho-punk Crass saw their debut album, The Feeding of the Five Thousand (1978), edited by their label, Small Wonder, following objections to the opening track, 'Reality Asylum', at the pressing plant (Berger 2009) and the group subsequently established their own independent label, Crass Records, to promote their message without interference. Other groups followed in their footsteps and a heavily politicised DIY punk network developed over the following decade (Glasper 2006). It should perhaps come as no surprise that others with differing ideological objectives might follow the same path.

\section{Rock-O-Rama Records}

German independent label Rock-O-Rama Records was one of the main producers and distributors of Rock Against Communism material during the 1980s and early 1990s. Founded by Herbert Egoldt in 1980, the label's initial releases were largely drawn from the apolitical punk scene in Germany, but it developed an affiliation to the emerging neo-fascist scene during the mid 1980s. This connection helped to grow the scene, though it did lead to controversy and eventually legal action that led to the closure of the label in 1994.

In the 1970s Egoldt set up a mail distribution company for American rockabilly bootlegs which he named Big H. In 1978 he opened his own store in Cologne under the name Rock-O-Rama. The focus of the store, and the ensuing label, was the voguish punk and new wave; even though Egoldt was an avowed fan of the blues, this revealed something of his entrepreneurial orientation when it came to business rather than (personal) pleasure. It was not until 1980 that Rock-O-Rama embarked on the production of its own records. The first release by Rock-O-Rama Records was the seven-inch single 'Punks Are the Old Farts of Today' by the German band Vomit Visions, and subsequent releases by Egoldt's new label were largely either apolitical or left-leaning German punk. The first international band to record for Rock-O-Rama Records was the British hardcore punk band Skeptix, from Stoke-on-Trent, with their 1983 debut album So the Youth. The same year Egoldt signed a two-year license agreement with the Finnish label Propaganda Records. This 
led to a series of releases featuring bands such as Riistetyt, Bastards and the Destrucktions whose covers featured, in the typical punk manner, the circled letter A or the hammer and the sickle.

The first overtly neo-fascist release from Rock-O-Rama Records was Der Nette Mann by German skinhead band Böhse Onkelz in 1984, which garnered some critical attention from the West German government for its overtly sexist and violent content and was subsequently banned. In the Böhse Onkelz biography, Danke für Nichts, the band recalled that,

Egoldt was a curious man. He was unreliable, hard to decipher and impenetrable. He was someone who would make something out of any demand. Egoldt was not a fascist or even someone politically engaged. It made absolutely no difference to him how he earned his money, and that made him extremely unpleasant. [author's translation] (Böhse Onkelz 1997 cited in Rock-O-Rama Records 2008b: n.pag)

Later that year, the album Hail The New Dawn by Skrewdriver (Figure 1) marked the transition of the label toward neo-fascist rock. As representative of the White Noise Club, Ian Stuart signed a contract with the German label and the majority of British neo-fascist rock production moved to Rock-O-Rama Records and its sub-labels.

Rock-O-Rama offered Skrewdriver a contract for one album and one single, which was accepted. Rock-o-Rama was in a position to offer better distribution and thus more exposure than White Noise Records. Moreover, and curiously despite the success of the 'White Power' and 'Voice of Britain' singles, White Noise Records did not have the money to release albums. (Interview with Ian Stuart in the fanzine Pure Impact Skins, cited in Forbes \& Stampton 2015: 119) 


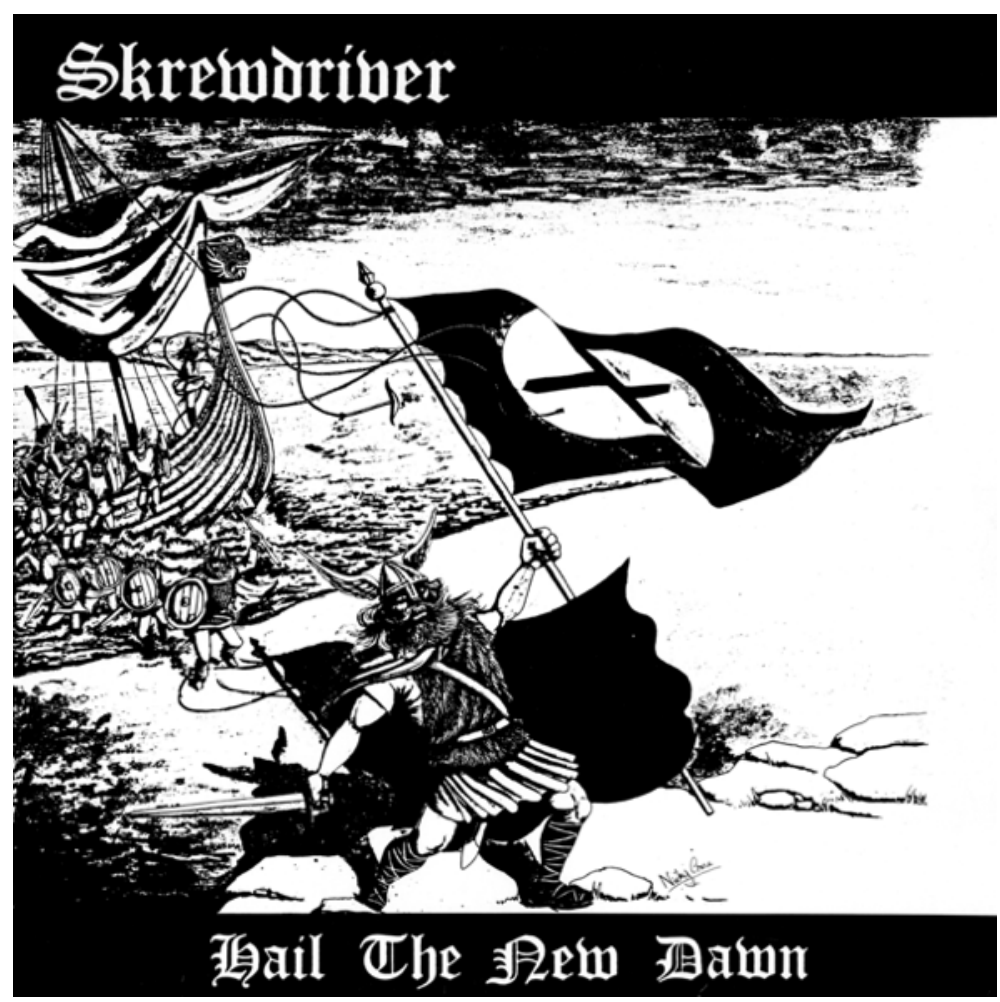

Figure 1 Skrewdriver (1984), Hail the New Dawn, vinyl album, Bruhl: Rock-O-Rama Records. Design by Nicola Vincenzo 'Nicky' Crane.

In 1986, Rock-O-Rama Records began to draw attention not only from fans but also from oppositional groups and activists, and the shop in downtown Cologne was closed. In order to divert attention from the label, Rock-O-Rama established a number of sub-labels for some of their new releases. These included White Power Records (from 1987 to 1991), United Records (from 1988 to 1991), Klan Records (solely for the production of Ian Stuart's rockabilly band the Klansmen, from 1989 to 1991) ${ }^{4}$, RAC Records (1989), Street Rock 'N' Roll (established solely for the production of seven-inch singles, most of which came in a generic company sleeve, from 1989 to 1991) and Ian Records (1990). Together with its sub-labels, Rock-O-Rama produced over sixty British neo-fascist rock records between 1984 and 1993, featuring some of the most renowned (and notorious) musicians and groups in the far right rock scene: Skrewdriver, Ian Stuart, Brutal Attack, Indecent Exposure, Public Enemy, Vengeance, Sudden Impact, Lionheart, White Diamond, Condemned 84, the Klansmen, No Remorse, Croydon Criminals, Skullhead and Squadron. In its full international catalogue, Rock-O-Rama Records listed almost 400 productions, including a significant number of far right releases.

\footnotetext{
${ }^{4}$ In 1987, Ian Stuart embarked on a side project under the name the Klansmen. This rockabilly band based their repertoire on the songs of the Ku Klux Klan and the American Civil War. Stuart assumed the alias of Jeb Stuart, after James Ewell Brown 'Jeb' Stuart - a Confederate States Army general.
} 
In the early 1990s, the German government initiated an investigation that would eventually lead to the closure of the label in 1994. Some of the documents of this investigation were compiled in a publication entitled 'Repression Against Rock-O-Rama' included as an insert with the 2008 compilation album Rock-O-Rama Records... Nach 30 Jahren Lieder aus der RAC-Ära: Teil 2. The document begins with a letter from the Anti-Defamation League to Chancellor Helmut Kohl, followed by letters from the German Justice Ministry and law enforcement organisations and concludes with a letter confirming the legal prosecution of the label. The production of new records came to a halt. After 1994, although some albums were still released through sub-labels, they consisted mainly of reissues and little original material was produced. ${ }^{5}$

Despite its original ostensibly apolitical position, the covers of the early punk releases on RockO-Rama Records were remarkably aggressive, featuring images of soldiers of the First and Second World Wars, bombs, hanged and crucified men. There are parallels here with other punk and post-punk related scenes, particularly anarcho-punk and the industrial and thrash metal scenes and, later still, what would become known as death metal, where shocking graphic images were widely used to communicate seriousness of purpose, risk-taking and an engagement with social and cultural extremes. However, despite this propensity for visual shock and its position as one of the major labels of Rock Against Communism - without equal in the history of far right rock - the covers of the neo-fascist releases are some of the least explicit and most metaphorical in the scene. Political symbols are scarce and frequently embedded in a general image.

A common design strategy, either on the front or back cover, is the display of live performance photographs, presenting an opportunity to expose three levels of information - the band, who frequently display political symbols on their clothing or accessories; the loyal fan base, the crowd, who also exhibit some of the same symbols; and the backdrops behind the stage, consisting mainly of flags or political symbols. The use of backdrops and objects integrated in the image act as what Roland Barthes describes as 'elements of a veritable lexicon, stable to a degree which allows them to be readily constituted into syntax' (Barthes 1977 [1961]: 23) and are one of the main sources of political symbols in Rock-O-Rama Records covers. Again, parallels can be drawn with the 1980s anarcho-punk scene, where flags, banners and backdrops were frequently displayed at gigs to communicate allegiance to certain causes, from generic anti-war symbols to more explicit support for anti-vivisection activists and hunt saboteurs. Symbols and images featured on record sleeves and backdrops were also incorporated in merchandise - badges,

\footnotetext{
${ }^{5}$ Herbert Egoldt died in 2005 of heart attack, at the age of 58. As all the rights regarding all Rock-0-Rama Records belonged solely to him, after his death the legal situation became unclear. Rock-0-Rama Records was re-launched in 2007 and is releasing new material alongside re-releases of old material.
} 
patches, t-shirts and other graphic ephemera, thereby taking the 'message' back into the street. Fanzines, such as White Noise and Blood \& Honour would often advertise t-shirts, badges, posters or stickers replicating or inspired by iconic music graphics from the scene (Figure 16).

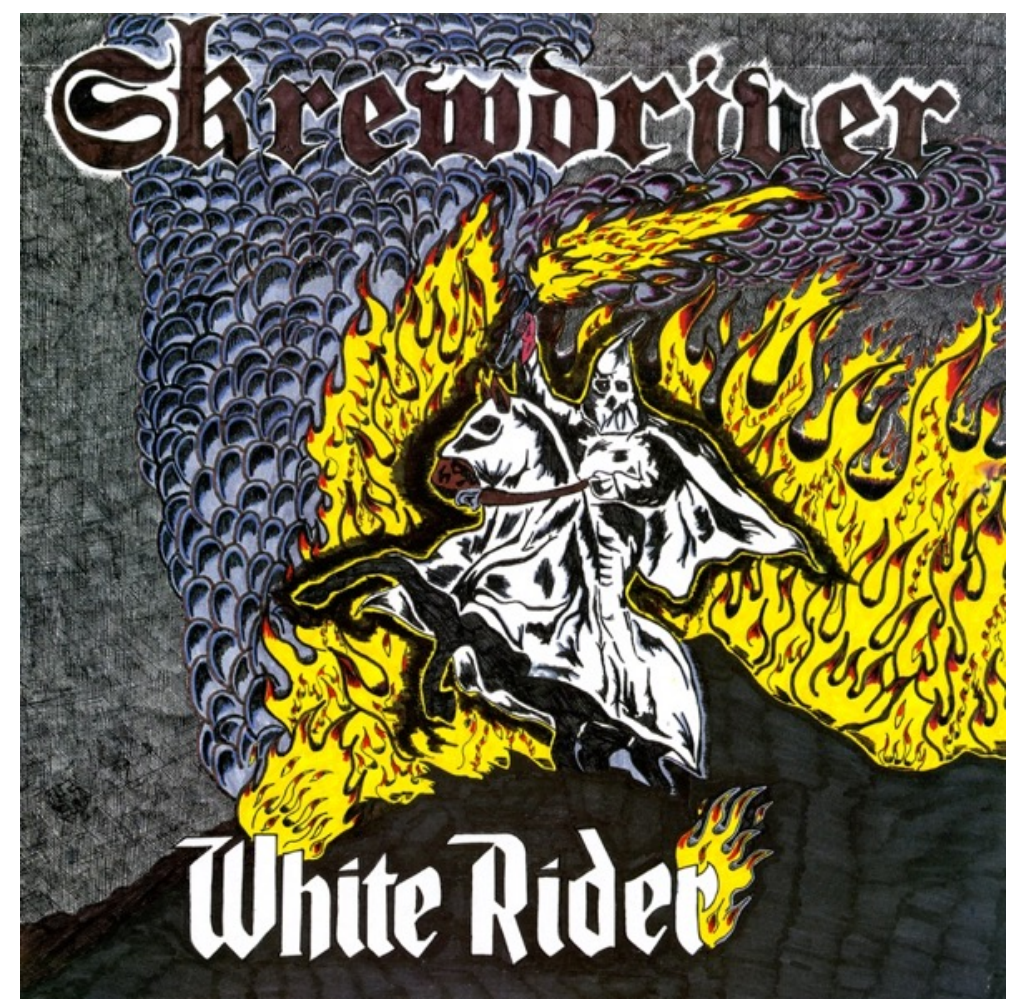

Figure 2 Skrewdriver (1987), White Rider, vinyl album, Bruhl: Rock-O-Rama Records. Design by Christian.

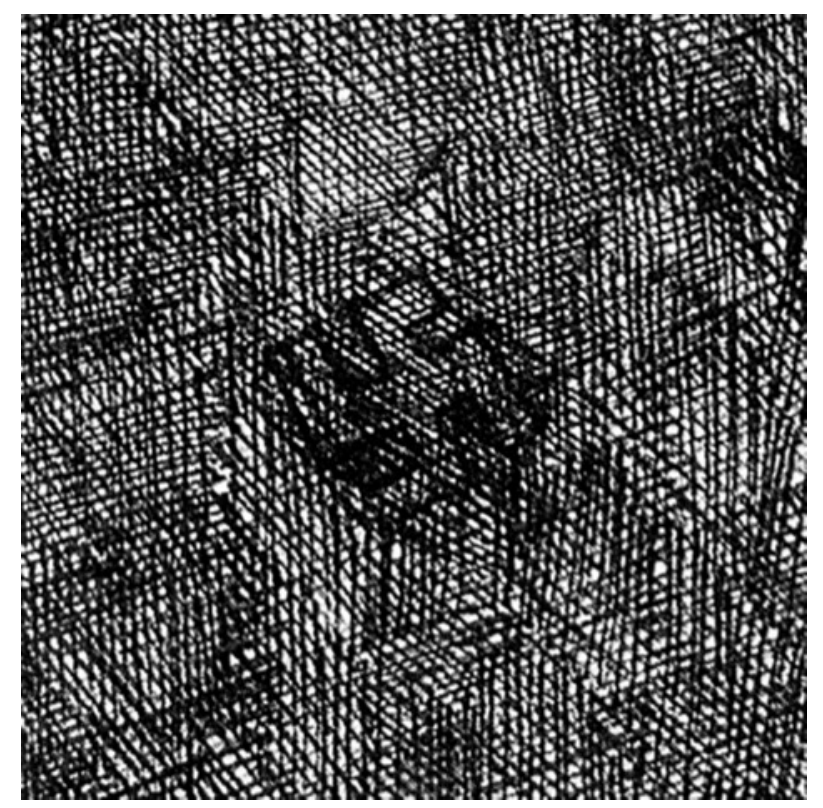

Figure 3 Hidden swastika on the cover of Skrewdriver (1987), White Rider, vinyl album (detail), Bruhl: Rock-O-Rama Records. Design by Christian. 
Few references to Nazi symbolism appear on the covers of early Rock-0-Rama releases associated with the far right skinhead punk scene: an SS death's head on a t-shirt partially concealed by a guitar strap on an album by Ian Stuart entitled Patriot (1991); an out of focus broken swastika on a banner on the back cover of the Skrewdriver album After The Fire (1988); and a few representations of eagles, though none specifically resemble the Parteiadler (the eagle above a swastika, official symbol of the German Nazi Party). A small swastika can be found in the bottom left corner on the cover of Skrewdriver's White Rider (1987) (Figure 2); however it is hard to perceive and it is not clear whether it was camouflaged - in an attempt to pass through Egoldt's quality control - or scratched out forcefully by adding a background texture composed of multiple overlapping hatch lines (Figure 3).

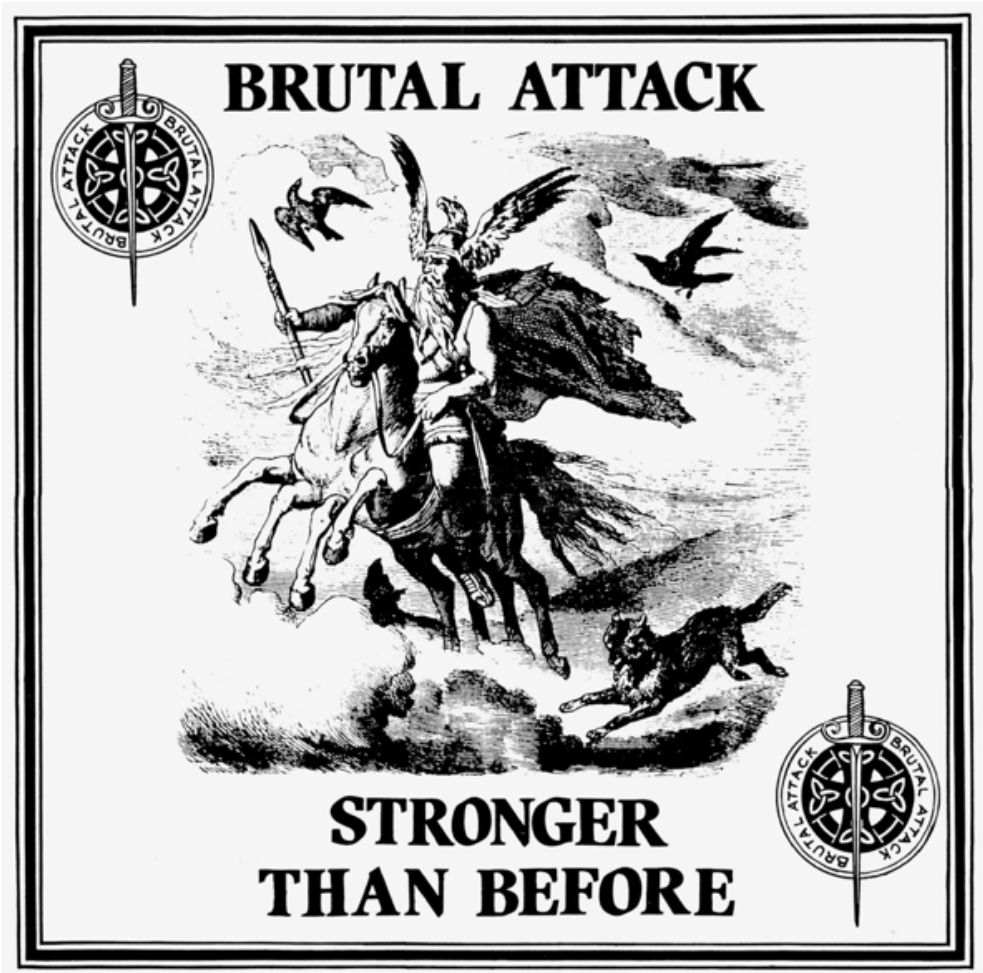

Figure 4 Brutal Attack (1986), Stronger than Before, vinyl album, Bruhl: Rock-O-Rama Records. Design by John Field. 


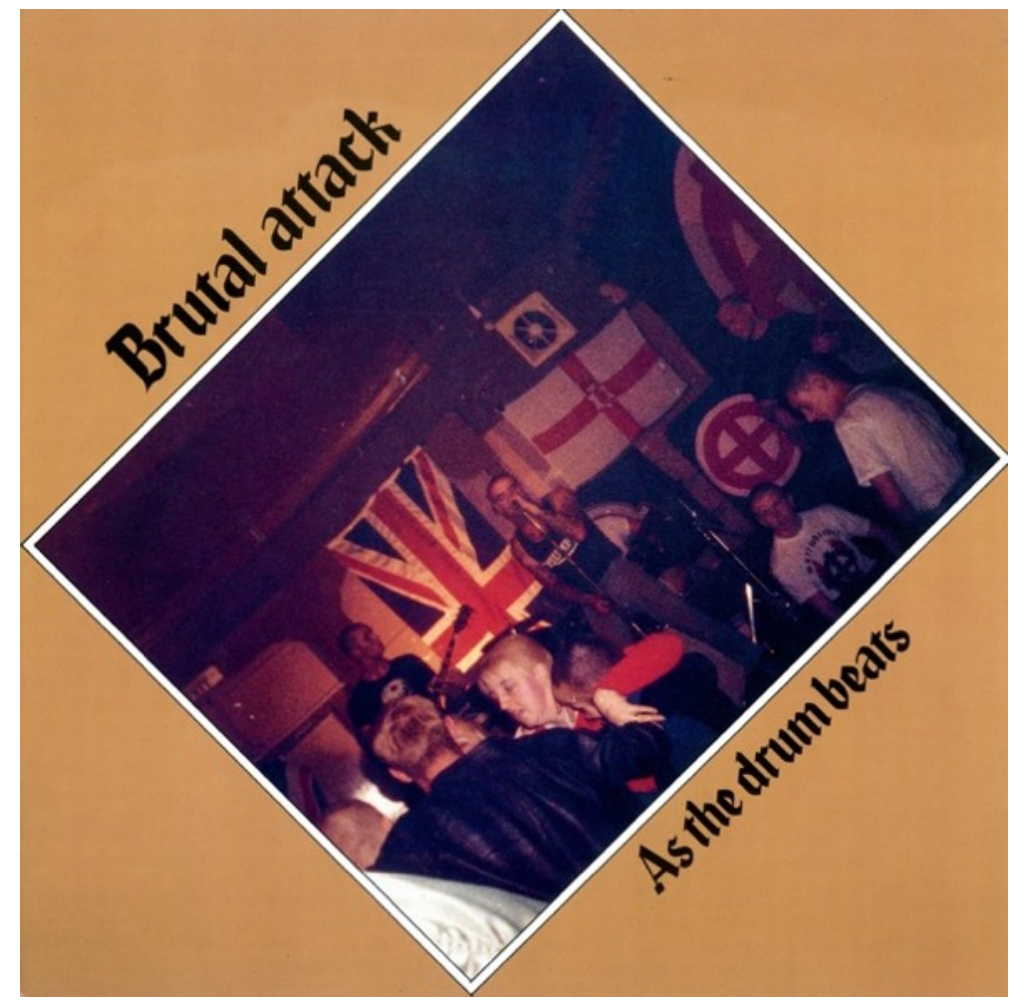

Figure 5 Brutal Attack (1988), As the Drum Beats, vinyl album, Bruhl: Rock-O-Rama Records.

This lack of explicit Nazi symbolism may be due to German law, which forbids their usage in publications and the media. A British fascist symbol does appear on record covers for albums by Brutal Attack: the Flash and Circle mark of the 1930s British Union of Fascists made its first appearance on the cover of the album Tales of Glory in 1989 and has been regularly used in visual material produced by the band since then. Brutal Attack had earlier complained of interference by Rock-O-Rama in their choice of album titles, with their proposed second album title Rocking for Race and Nation considered 'too harsh' and re-titled As the Drum Beats by the label (Figure 5),

'Rocking for Race and Nation' or 'Rockin' For R'n'N' as it appears on both the sleeve and the record label thanks to the interference once again of Rock-O-Rama Records continues in a similar lyrical vein to R.A.C. (Forbes \& Stampton 2015: 300)

More prevalent across many of the Rock-0-Rama releases are national symbols such as the Union Flag, the St. George's Cross and the controversial Ulster Banner, either within backdrops on live performance shots or on flags carried in illustrations. 


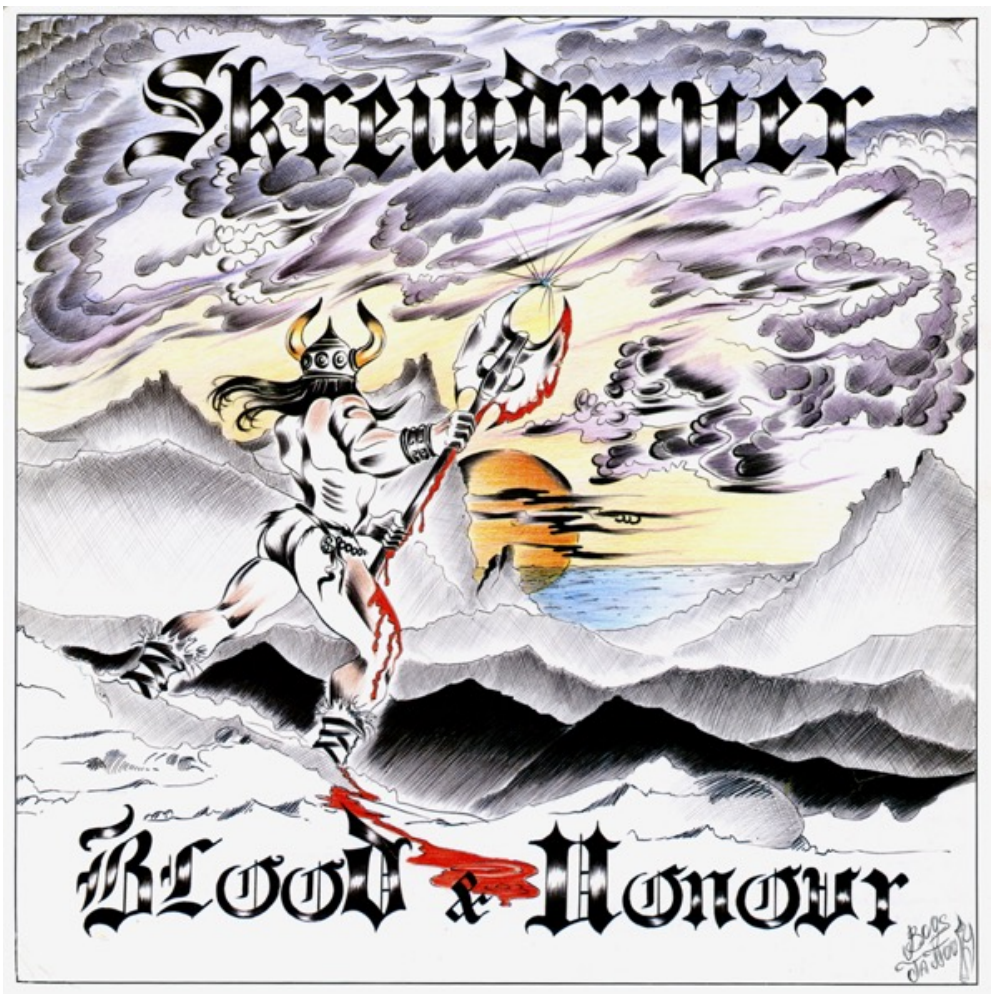

Figure 6 Skrewdriver (1985), Blood \& Honour, vinyl album, Bruhl: Rock-O-Rama Records. Design by Bugs Tattoo.

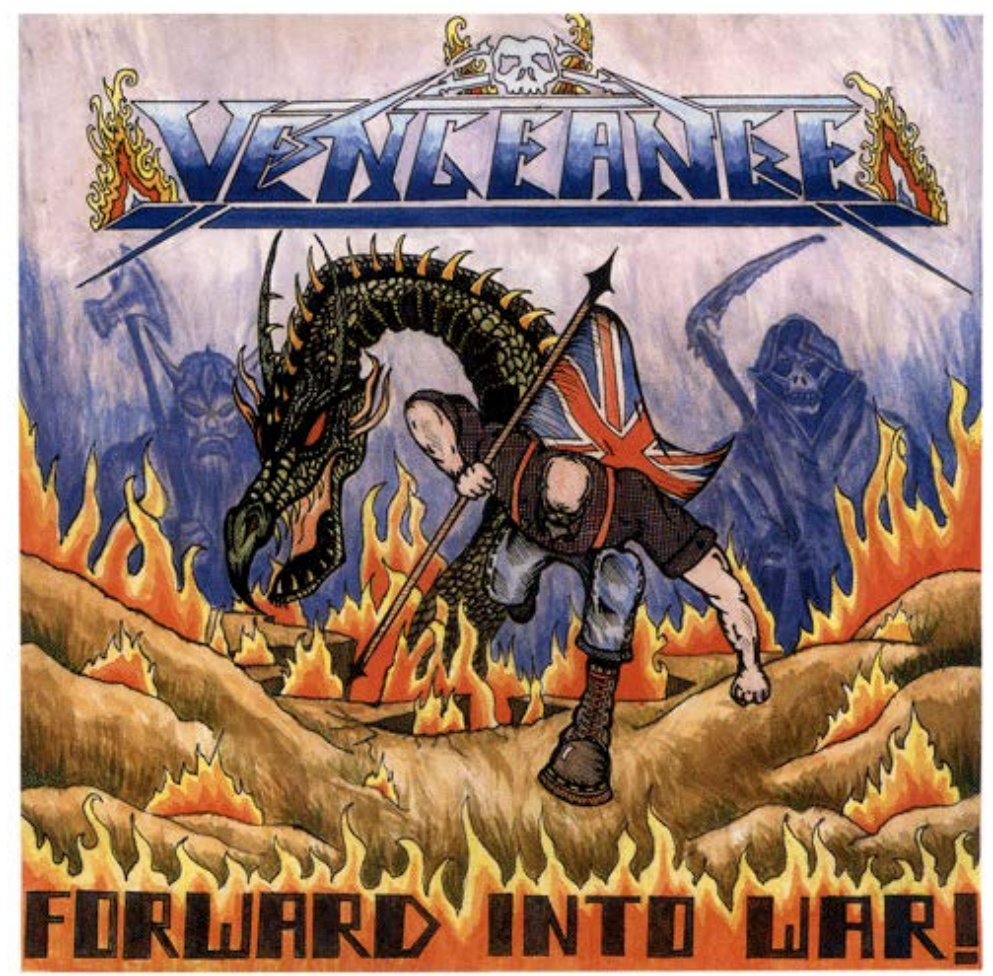

Figure 7 Vengeance (1988), Forward Into War, vinyl album, Bruhl: Rock-O-Rama Records. Design by Vernon. 
A wider visual strategy employed the use of metaphorical images, particularly illustrations of mythical warriors fighting adversity. Skrewdriver's Hail The New Dawn (1984) (Figure 1) depicts Viking warriors disembarking from a ship, while the Blood \& Honour album (1985) (Figure 5) features a Viking warrior with blood dripping from his axe standing guard on the coast. The cover of Forward Into War by Vengeance (Figure 6) shows a skinhead carrying the Union Jack emerging from a flaming battlefield - a visual claim for endurance and survival. The paramount concern manifested through the imagery in the sleeves relates to nation. The usage of Norse imagery indicates the ideal of the preservation of a pure Aryan race in Northern Europe associated with Teutonic mythology. The conceptual alliance forged between skinheads and Viking warriors establishes the link between contemporary and historical defenders of the white race and their soil from invaders, while claiming their Aryan heritage.

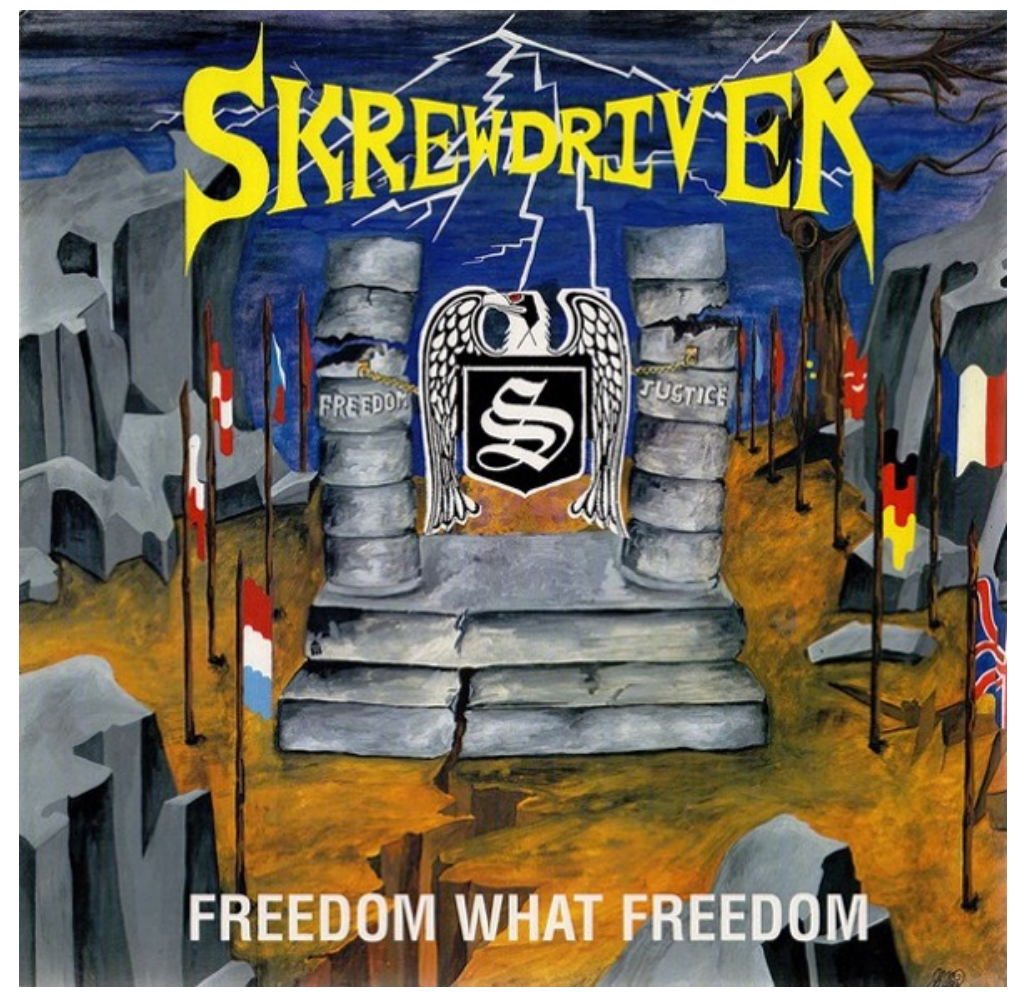

Figure 8 Skrewdriver (1992), Freedom What Freedom, vinyl album, Bruhl: Rock-O-Rama Records.

The Skrewdriver album Freedom What Freedom (1992) (Figure 8) takes a rather unorthodox approach by referencing a story from the Tanakh (the Hebrew bible), with the band's logo chained between two pillars. As Samson - to whom God granted superhuman strength to combat his enemies - had done, Skrewdriver is breaking the pillars that contain it. The intention of the analogy is ambiguous: the consequence of Samson's actions are that when the temple collapses his enemies are destroyed but at the cost of his own life. Despite the atypical approach, this 
indicates a recurrent theme; the persecution of the members of the movement. Claims of repression often relate to official government punishment of the scene, intermittently attributed to the takeover of the national government by what is termed the Zionist Occupation Government (ZOG). ${ }^{6}$ Claims for justice are presented either for actual situations, as in the mini album Justice For The Cottbus Six by Ian Stuart and Rough Justice (1992), when six neo-fascists including members of Skrewdriver were imprisoned in Germany; or as a collective appeal to support 'all our friends who are either in prison or awaiting trial for fighting for their friends and family' (Skullhead 1991). The claim to stand for fallen comrades reinforces the notion of unity and common purpose. Additionally, it relates to the commonly employed theme of martyrdom, of heroes willing to sacrifice themselves for the cause.

Subcultural representations are also used to reinforce the notion of strength and unity. Skinheads - in particular the archetypal, neo-fascist skinheads with shaved heads and high combat boots are presented stomping over an invisible foe, as on the 1986 EP by Vengeance (1988); as an army, as on the compilation album No Surrender! Vol. 3 (1989); or going into battle, as on Forward Into War, also by Vengeance (1988) (Figure 7). Occasionally, the representation of skinheads is achieved through an iconic element of the subculture, such as the combat boots on the sleeve of the album Boots and Braces by Skrewdriver (1987).

Rock-O-Rama Records also established a number of sub-labels ranging from medium-sized enterprises, such as First Floor Records, based in Germany, and White Power Records, based in the United Kingdom, to those dedicated to a single band, such as Ian Records for releases by Ian Stuart, Klan Records (the Klansmen) and Brutal Attack Records (Brutal Attack). These labels, many based outside Germany, reveal greater tolerance of the use of neo-fascist symbolism. Odal runes are openly displayed, as on the sleeve of the album Take The Sword by Squadron (1991) on White Power Records. Squadron later recounted a number of issues with Egoldt and their frustration with hold-ups attributed to the pressure activists were putting on his label,

Rock-O-Rama are very hard to contact. Herbert is never there! We only find out that an album is out when we see it! He never consults us about what is or isn't acceptable, hence our first album was censored. If he'd told us and sent it back, we would have replaced the picture with less provocative ones! It took four years to get our royalties out of him. We ain't made of money. Guitars, amps and strings don't grow on trees!

\footnotetext{
${ }^{6}$ The ZOG consists of an anti-Semitic conspiracy theory involving the complete control of a façade official government by the Jews.
} 
Herbert has had a lot of trouble lately, the Anti-Defamation League are watching him closely at the moment. Our third album is recorded and has been at Rock-0-Rama for four months. It should be out soon. (Interview with Brad of Squadron in US fanzine On the Frontline no.3, 1993, cited in Forbes \& Stampton 2015: 517)

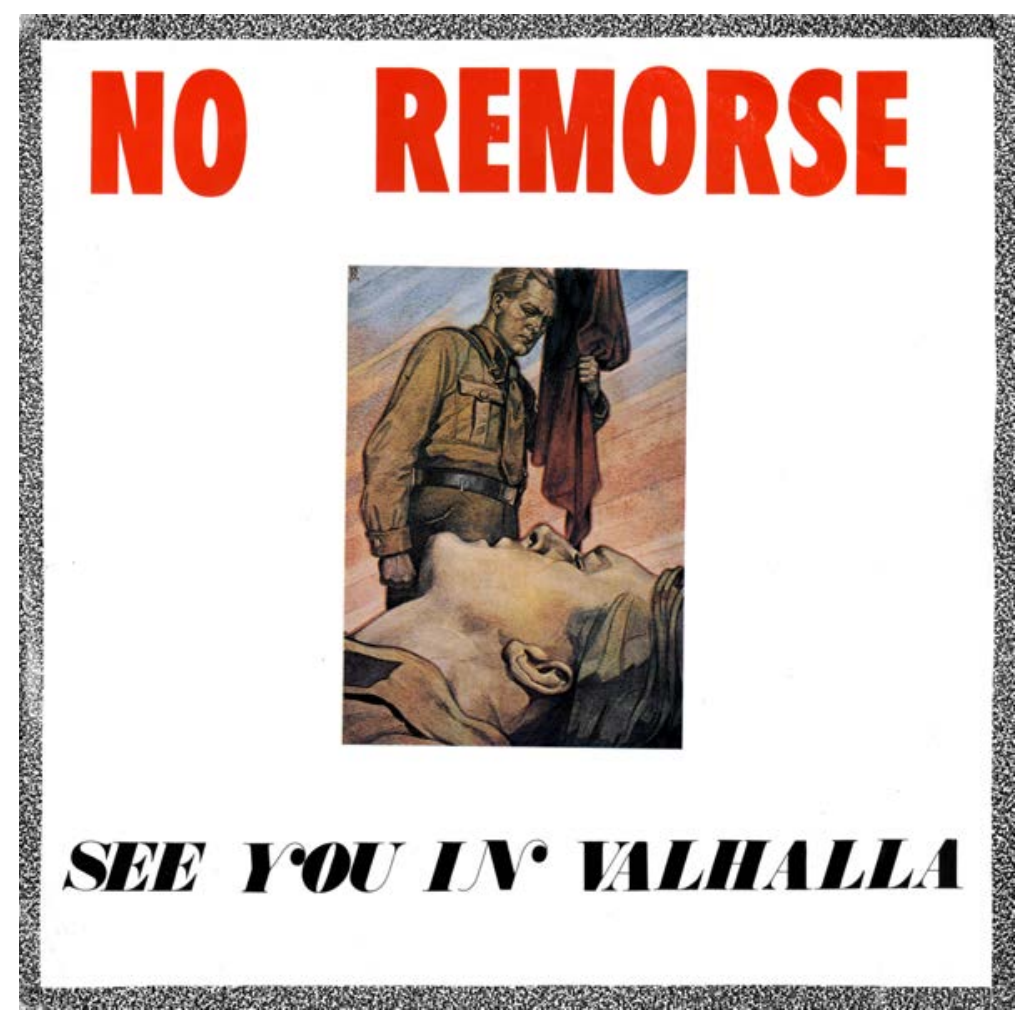

Figure 9 No Remorse (1989), See You In Valhalla, vinyl album, London: RAC Records.

The Celtic cross is allowed to assume a privileged position on the cover of the Skullhead album White Warrior (1987) on United Records and an eagle resembling the Parteiadler is shown on the back cover of the album The New Stormtroopers by No Remorse (1989) on the RAC Records sublabel. However, despite the more explicit display of neo-fascist symbols, the swastika was still off limits. The sleeve of the album See You In Valhalla by No Remorse (1989), also on RAC Records, employed an illustration by Felix Albrecht, a SS-Sturmführer and collaborator with the Reichspropagandaleitung of the NSDAP (the Central Party Propaganda Office of the German Nazi Party) and Reichsführer-SS (the commander of the SS). Albrecht's original illustration entitled Fallen Comrade featured a swastika flag but it was changed to a plain flag on the album cover (Figure 9). ${ }^{7}$ Presumably, the decision to obscure the swastika can be attributed to the label, as No Remorse bluntly exhibited swastikas on releases for Rebelles Européens the same year. On the

\footnotetext{
${ }^{7}$ The illustration was included in the notorious book Deutschland Erwacht published by CigarettenBilderdienst Hamburg-Bahrenfeld in 1934 as a tribute to the Nazi Party. The book featured an extensive selection of work by Felix Albrecht.
} 
band's third album, The New Stormtroopers (1989), the Parteiadler carries a Celtic cross instead of a swastika and, unusually, the uniformed individuals on the front cover do not carry any patches or insignia.

\section{White Noise Records}

White Noise Records, the first British neo-fascist label, actually pre-dates the contract signed by Stuart with Rock-O-Rama, having been launched in 1983 as a dedicated far right record label, though its impact was relatively small due to a lack of funds and problems with marketing and distribution. Only four records were ever released - two seven-inch records by Skrewdriver and two compilation EPs. One further seven-inch single appeared on the sub-label Counter Culture Records.

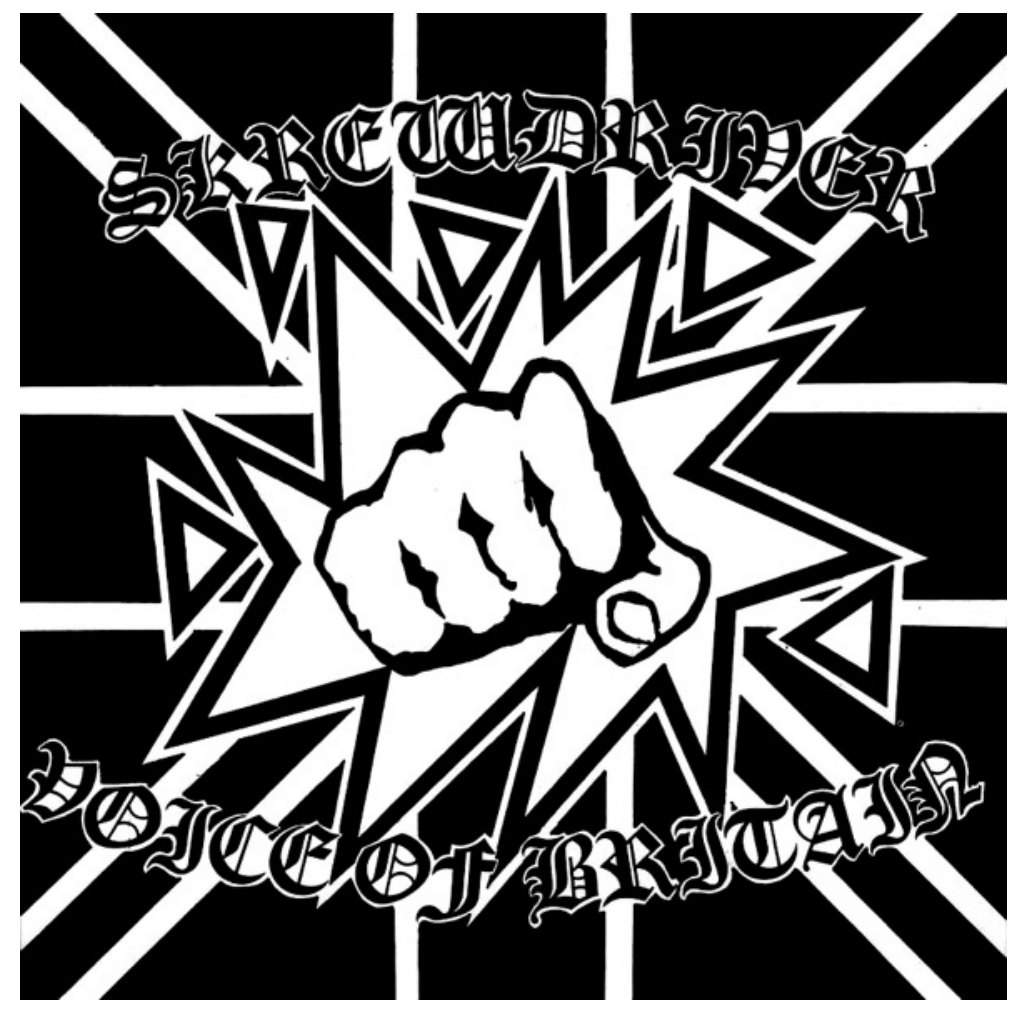

Figure 10 Skrewdriver (1984), Voice of Britain, vinyl 7" single, London: White Noise Records. 


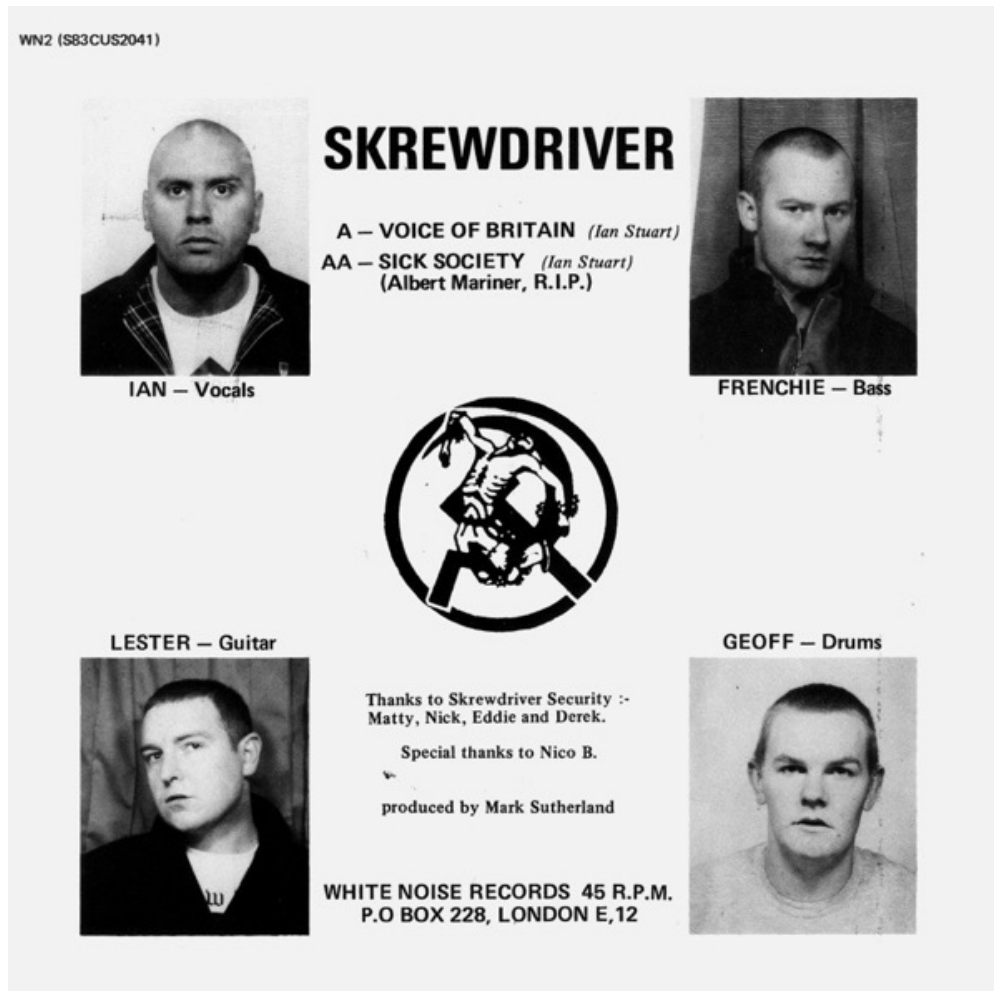

Figure 11 Skrewdriver (1984), Voice of Britain, vinyl 7" single back cover, London: White Noise Records.

The first release by the label was the White Power EP by Skrewdriver in 1983. The front sleeve displayed an Aryan fist set against a black background. Even though Skrewdriver had released the Back With A Bang twelve-inch EP the year before on the Boots 'n' Braces label, the back sleeve of White Power states 'Skrewdriver are back!'. As such, this is the first record to clearly state the intention behind the newly restructured band - White Power. The label's second release, also by Skrewdriver, was the single 'Voice of Britain', in the same year. The front sleeve displayed a clenched fist punching through the Union Jack (Figure 10), while the back featured the crucified skinhead illustration from RAC News (Figure 11). The symbol is a clear subversion of Karl Geiss's poster 'The Worker in the Reich of the Swastika' designed in 1932 as an election poster for the German Social Democratic Party (Pachnicke \& Honnef 1992: 39). ${ }^{8}$

\footnotetext{
${ }^{8} \mathrm{~A}$ well-known version of the concept was the photomontage created by John Heartfield for ArbeiterIllustrierte-Zeitung (AIZ), 'As in the Middle Ages... So in the Third Reich in 1934' (Pachnicke \& Honnef 1992: 201), however the symbol devised for RAC News undoubtedly refers to the more obscure poster designed by Karl Geiss.
} 


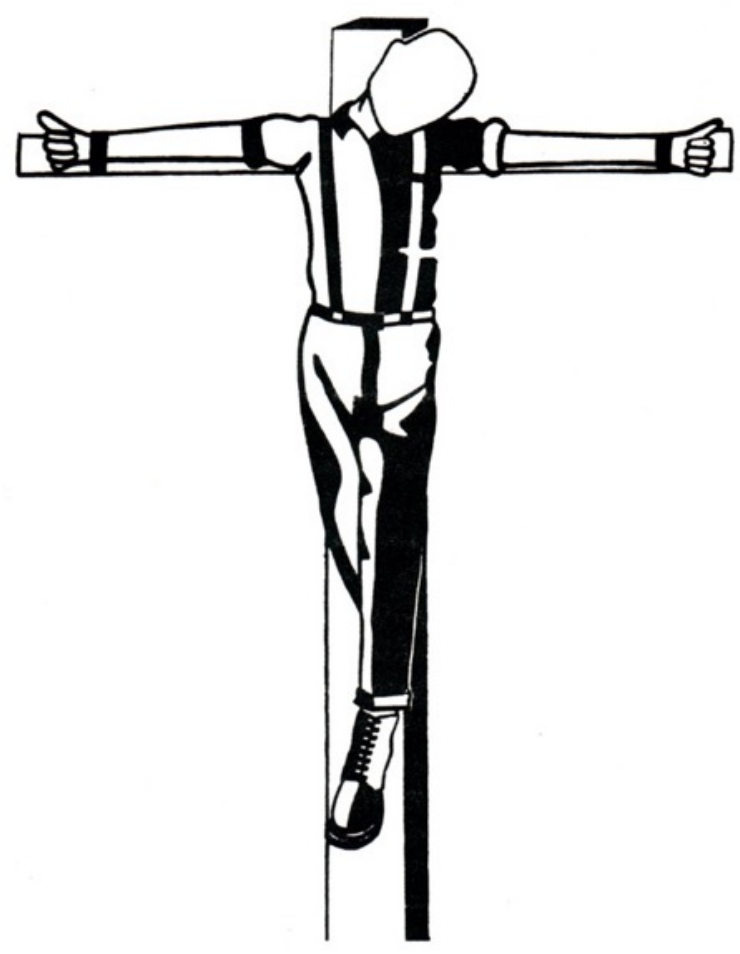

Figure 12 (c1980), Crucified skinhead image, London: The Last Resort, designed by Mick Furbank.

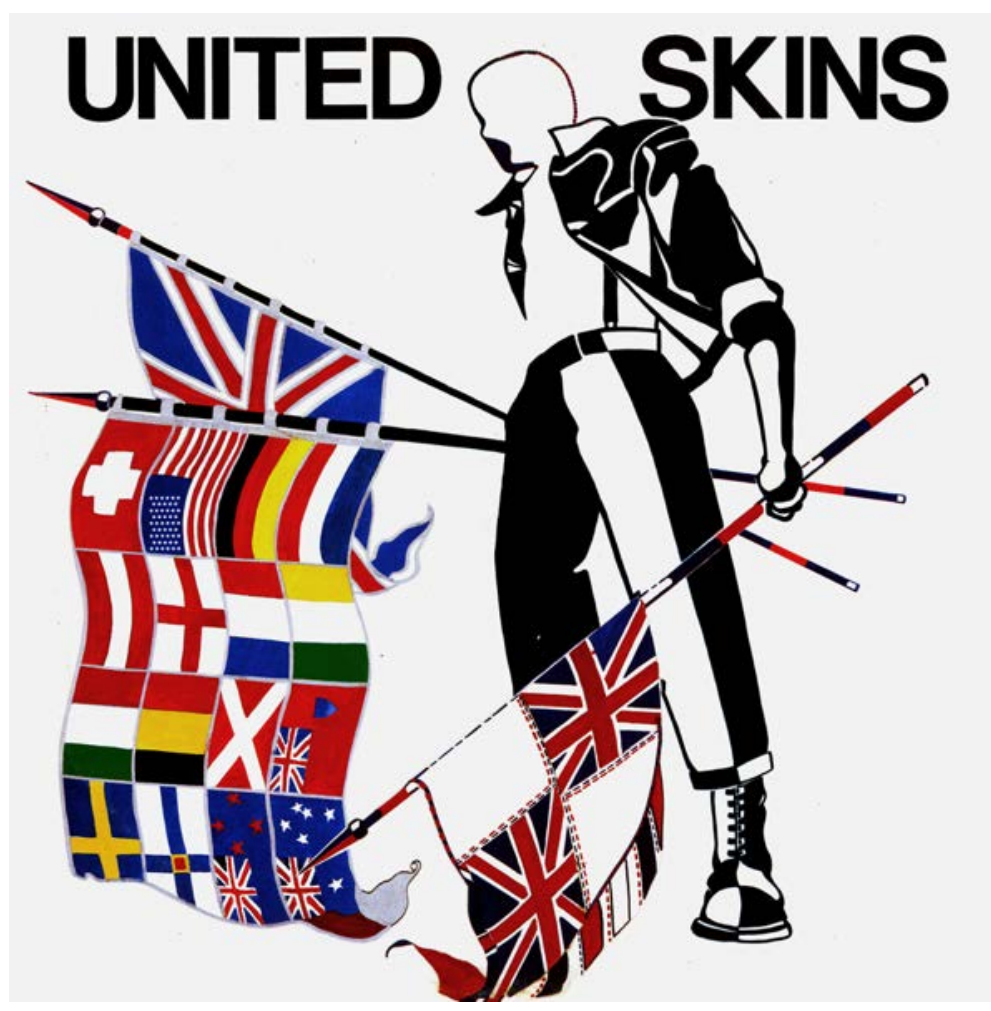

Figure 13 Various Artists (1982), United Skins, vinyl album, London: Boots \& Braces. Design by Mick Furbank. 
Arguably, it also makes reference to a widely-referenced symbol designed by Mick Furbank for The Last Resort shop - a haven for all skinhead factions in London (Figure 12). The crucified skinhead represents the difficulties faced by participants in the skinhead movement and could be seen in the cult t-shirts section of The Last Resort catalogue in the early 1980s, alongside others featuring the iconic skinhead drawings by Furbank, who also created illustrations for album covers within the skinhead punk and Oi! scene (Figure 13).

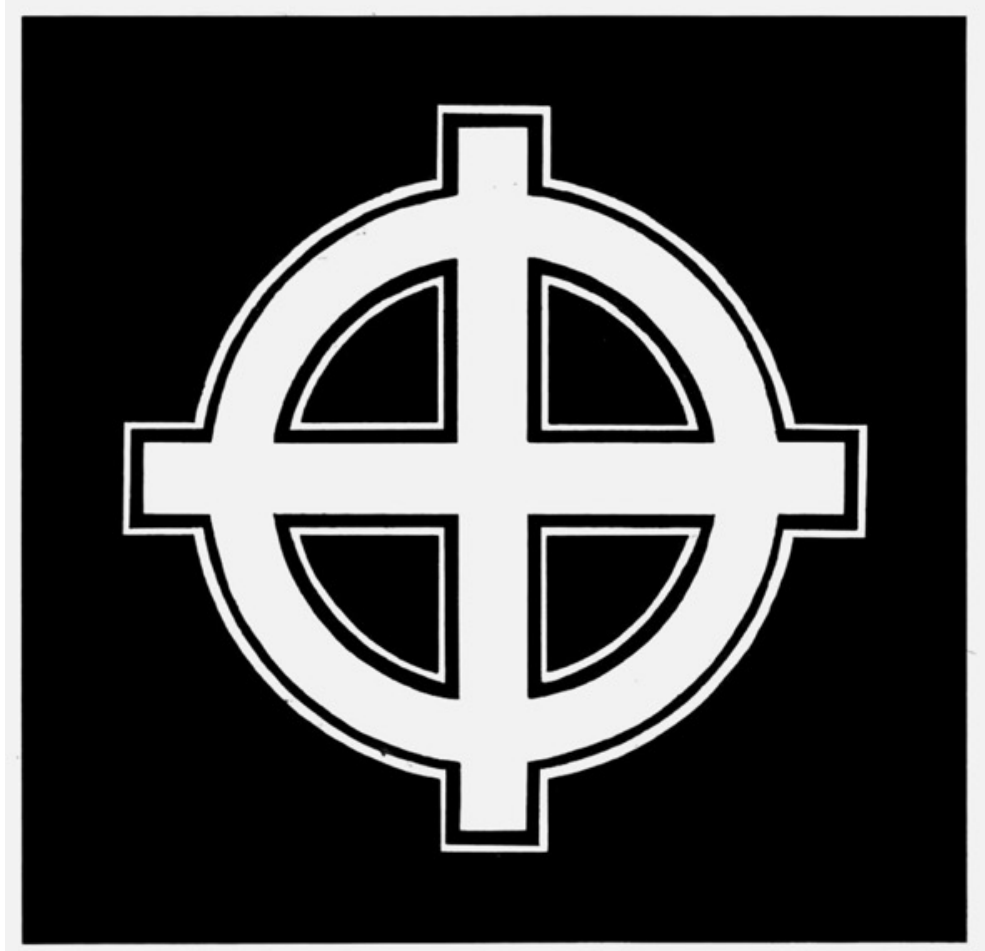

Figure 14 Skrewdriver, Diehards, Brutal Attack \& A.B.H. (1984), This is White Noise, vinyl 7" EP, London: White Noise Records. 


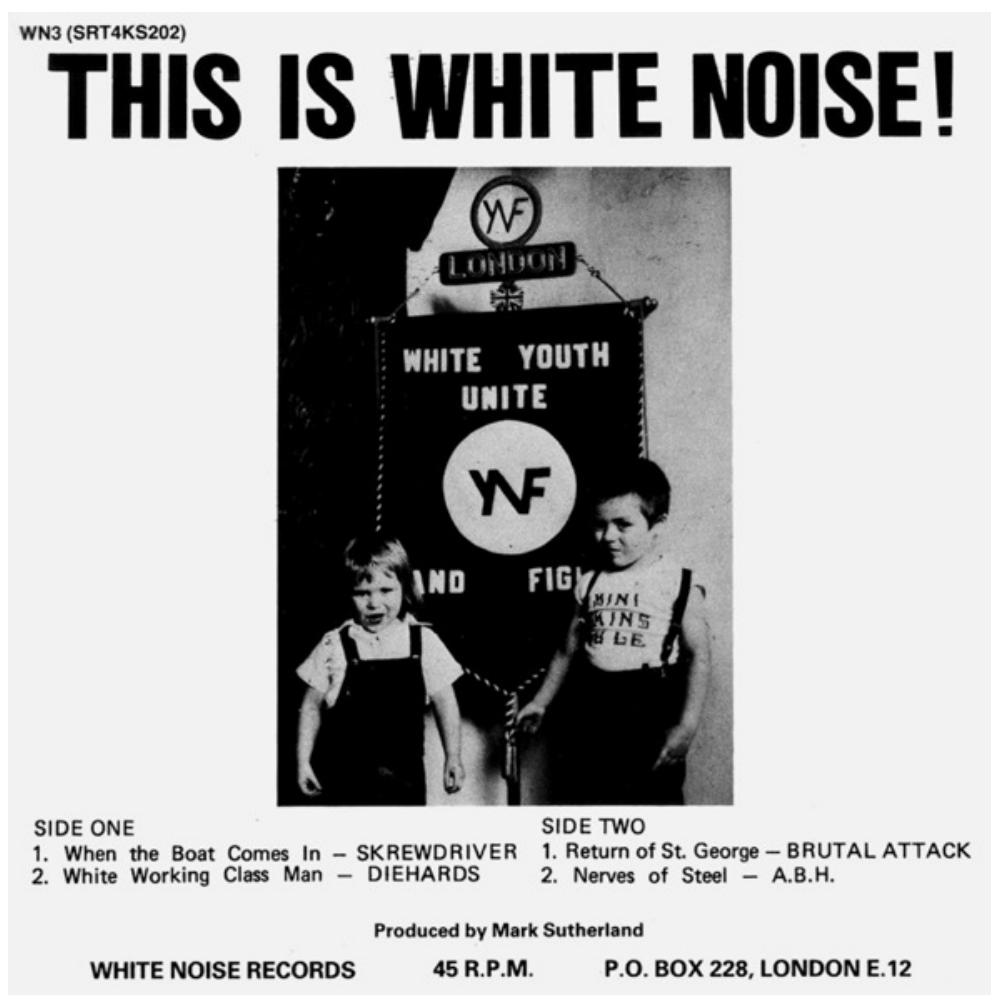

Figure 15 Skrewdriver, Diehards, Brutal Attack \& A.B.H. (1984), This is White Noise, vinyl 7" EP back cover, London: White Noise Records.

The seven-inch compilation EP This Is White Noise! was released in 1984 and included tracks from Skrewdriver, Diehards, Brutal Attack and A.B.H. (Figure 14). The front sleeve featured a white Celtic cross with a black background, while the back sleeve listed the output from White Noise Records, at the same time more clearly establishing the link between the label and the party through the inclusion of a photograph of two youths holding a Young National Front banner (Figure 15).
For neo-fascists, the Celtic cross, in particular, became a statement of ideological intent - not least because it was a bold, powerful symbol and easy to graffiti. So, just as the circled ' $\mathrm{A}$ ' had become the calling-card of the anarcho-punks, so the Celtic cross was the riposte. (Raposo and Sabin 2017: 135)

All releases from the first period of White Noise Records featured high-contrast black and white sleeves displaying strong iconographic symbols on the front. The first releases from British bands associated with the White Noise Club on Rock-O-Rama Records continued this established visual trope. This tendency was only broken by the album Blood \& Honour released by Skrewdriver in 1985, the fourth release on Rock-O-Rama Records under the terms of the White Noise Club contract (Figure 6). 
The scene was changing rapidly by this point, not only in reaction to being driven underground but also sartorially and aesthetically with the adoption of a range of tropes and symbols that offered coded messages to fellow travellers,

Things had changed by 1984. The far right had all but moved away from contesting youth cultural forms and styles towards forging its own particular variant, releasing its own records by its own bands to an audience defined by a stylistic off-shoot of a skinhead culture that resisted claims to its identity. Black MA1 jackets, high boots, fully-shaved heads, Celtic crosses and Nordic symbols became the 'uniform' of a Naziskin some way from the more polished look of the 'sussed' or 'traditional' skinhead (whose musical tastes leant towards soul, ska and early reggae). (Worley and Copsey 2017: 121)

This 'new variant' of far right skinhead culture developed not only stylistic conventions in dress and symbolism but also a DIY network for marketing and distribution of their products - records, t-shirts, badges, fanzines and other ephemera - through mail order and at live gigs and gatherings (Figures 16 and 17). In part this was driven by necessity, as the public face of the scene shifted further right to embrace neo-nazi tropes, Holocaust denial and overtly racist ideologies and was widely banned as a result. A recurring theme of persecution and victimhood runs deep in far right political groups and was a key visual and textual trope within the neo-nazi skinhead punk scene: the image of a genuinely countercultural subculture ostracised by mainstream political groups and the media only furthered the scene's appeal to its core adherents. 


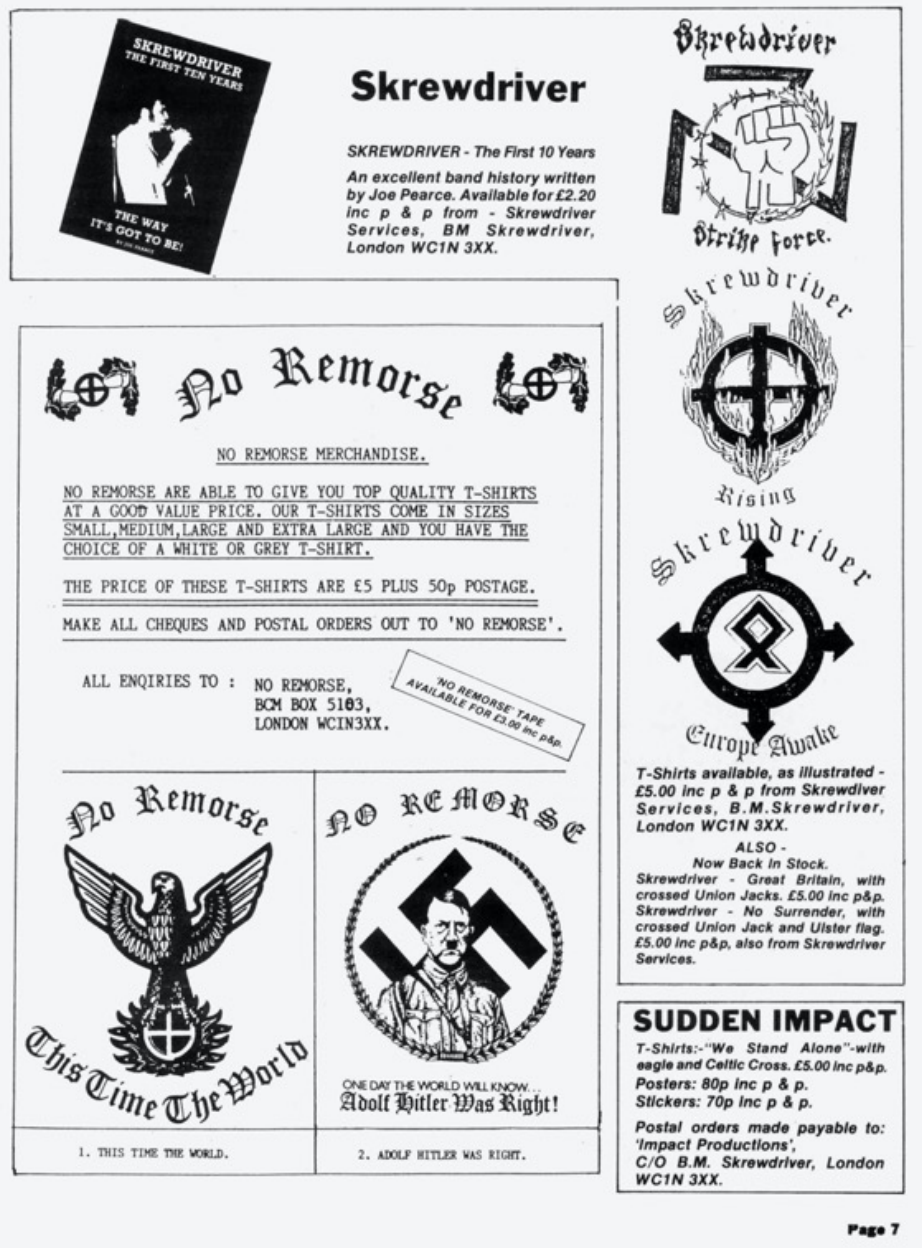

Figure 16 T-shirt advert, Blood \& Honour (1987), issue 1, page 7. 


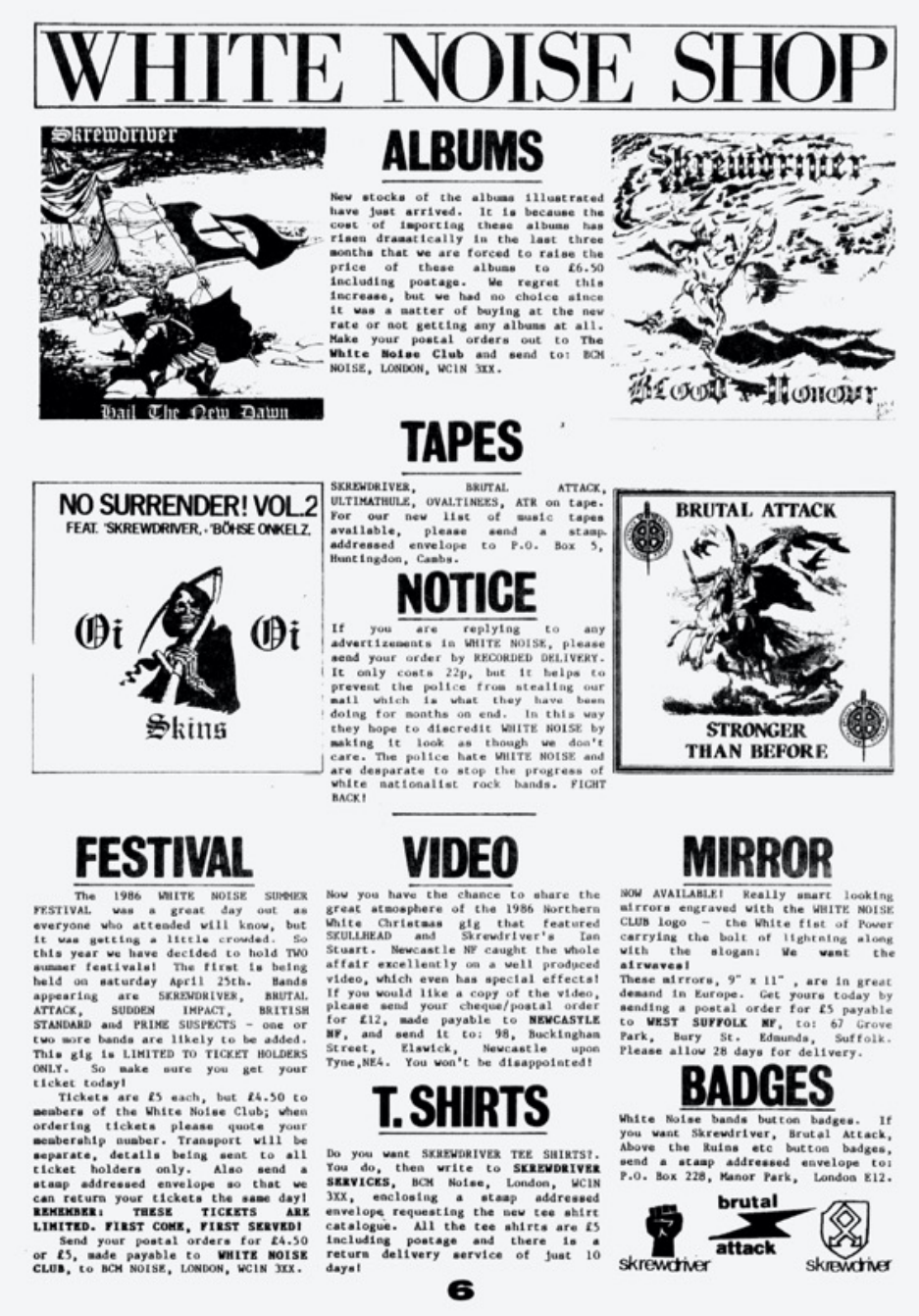

Figure 17 White Noise Shop advert, White Noise (1987), issue 3, page 6.

In 1988, White Noise Records made a last ditch effort attempt to enter the music scene with the twelve-inch split single 'We Want the Airwaves' by Skullhead and Palazard. ${ }^{9}$ The single addresses the aspiration of bringing the neo-fascist music to the mainstream in a period when it was being driven increasingly underground by anti-fascist organisations and legal restraints. White Noise Records and the White Noise Club withered soon afterwards.

\section{Rebelles Européens}

Rebelles Européens, a label based in the port city of Brest in northern France, was set up in 1987 by Gael Bodilis and Brigitte Maljak - members of the Front Nationale Jeunesse (the French Young National Front). The label released forty-five twelve-inch records and thirty seven-inch records

\footnotetext{
${ }^{9}$ The title clearly references the 1981 single 'We Want the Airwaves' by the Ramones, though there are no further references in either the lyrics or graphics.
} 
by European bands between 1987 and 1994, including records by the British bands No Remorse, Public Enemy, Lionheart, Battlezone, Violent Storm, Paul Burnley and the Fourth Reich, Grade 1, The Soccer Hoolys, English Rose, the Ovaltinees and Skullhead.

Rebelles Européens was active contemporaneously with Rock-0-Rama Records. However, while Rock-O-Rama Records was created as an apolitical label by Herbert Egoldt, who did not share the political vision of the scene and was solely concerned with its business potential, Gael Bodilis, was deeply engaged in the political scene and thus politics were the main impetus for Rebelles Européens. Furthermore, the affiliation to the movement led to a bond with the bands that RockO-Rama Records lacked. Bodilis declared in a skinzine interview that,

The reason for its creation was quite simple, no label wanted to produce politically engaged bands without self-censorship... I had to give them the same opportunity to do so as other bands... Music is an excellent way of spreading those ideas and it was becoming more and more necessary to have these skinhead bands known. Obviously there is one factor that I am not interested in PROFITABILITY. The Jews could probably talk about it better than I do. (Lowles \& Silver 1998: 13)

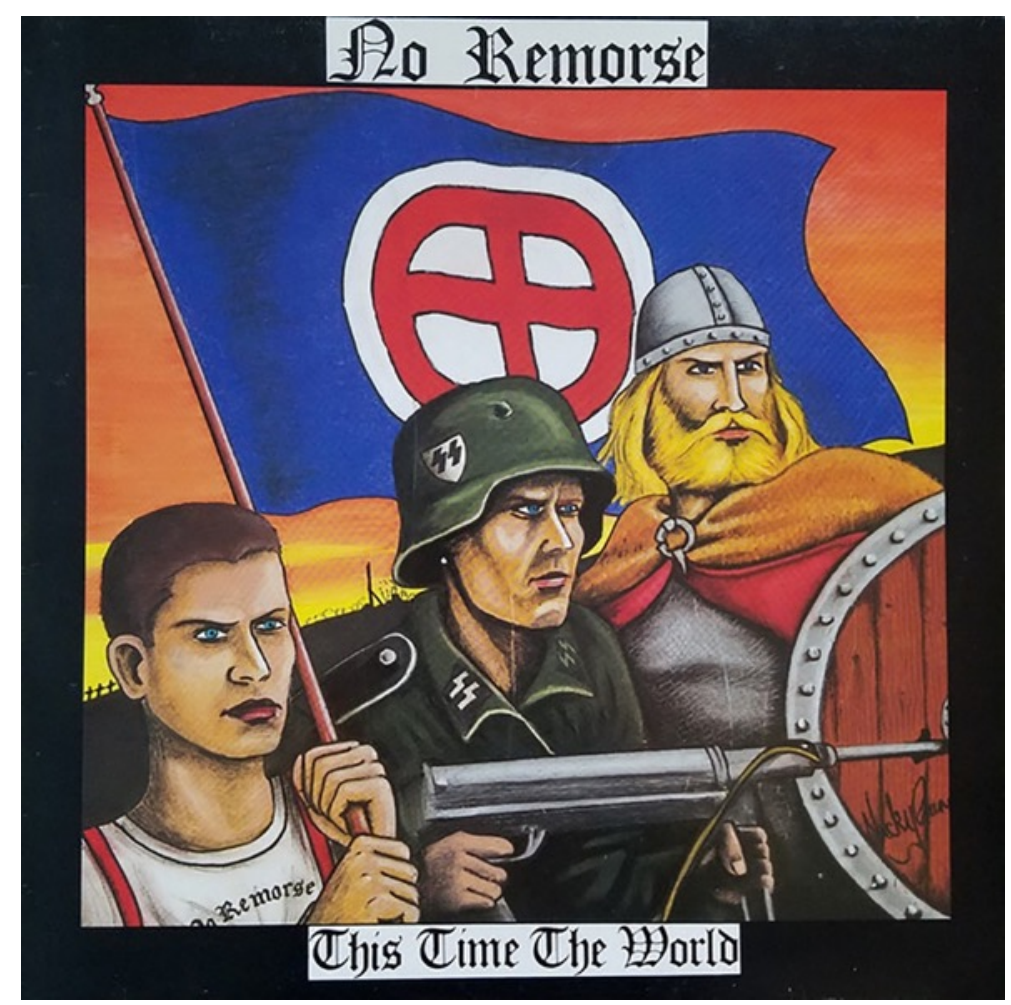

Figure 18 No Remorse (1988), This Time The World, vinyl album, Brest: Rebelles Européens. Design by Nicky Crane. 
The first British release on Rebelles Européens was This Time the World by No Remorse in 1988, an album which once again drew its title from historical allusion,

This Time the World was inspired by the book of the same title, the autobiography of George Lincoln Rockwell, who founded the American Nazi Party in 1959. (Forbes \& Stampton 2015: 279)

Lyrically, too, this album represented something of a sea-change for the white nationalist scene in its explicit calls for violent activism on songs such as 'We Salute You (R. Hess)', 'Smash the Reds' and 'Hail the Order',

Musically, the album is competent Oi! although some might be tempted to label it Nationalist rock or white rock music. However, what really sets this album apart from all other Nationalist records which have gone before are the lyrics. Some are extreme. Some are explicit. Some incite racial violence. Some are crude. Some are taboobreaking. And yet this did not deter Rebelles Européens from releasing such a 'ground-breaking' and controversial album. Curiously, Rebelles Européens seemed to operate without regard to the law. (Forbes \& Stampton 2015: 281)

The sleeve, designed by leading neo-nazi activist Nicky Crane, represents three generations of white warriors united in a battlefield; a Viking, an SS officer and a skinhead carrying a flag bearing the Celtic cross (Figure 18). The ascending figures with a fixed stare, looking at something we cannot see beyond the frame (hors champs), resemble a construction from classical painting, particularly from the Romantic period of the late eighteenth and early nineteenth centuries. ${ }^{10}$ Similar styles were utilised on propaganda paintings in the early twentieth century, including Soviet and Nazi posters from the 1920s and 1930s.

The skinhead on the cover of This Time the World physically resembles Paul Burnley, the lead singer of No Remorse. ${ }^{11}$ Unlike previous releases on Rock-O-Rama Records, the Celtic cross and the parallel Sig runes of paramilitary Nazi group Schutzstaffel (SS) are openly displayed on the front cover. The back sleeve features a photograph of the white generation they are defending, three children performing the Nazi salute over a flag with the Celtic cross. Additionally, it also

\footnotetext{
${ }^{10}$ For instance the French Romantic paintings of Eugène Delacroix (1798-1863).

${ }^{11}$ Paul Burnley was a leading figure of the British neo-fascist scene and fronted the bands No Remorse, Public Enemy and Paul Burnley and the Fourth Reich.
} 
displays a Parteiadler carrying the Celtic cross, which had appeared in a previous release on RAC Records, a subsidiary label of Rock-0-Rama Records.

No Remorse original singer Paul Burnley then formed a new band, Public Enemy, in the process adopting an even more hardline, antagonistic approach. ${ }^{12}$ The group released their debut album There is Only One... Public Enemy on Rebelles Européens in 1988, the back sleeve featuring a Parteiadler now carrying a swastika. Rebelles Européens systematically incorporated Nazi imagery into their graphics: in the same year, 1989, the seven-inch single 'Waiting for the Storm' by Public Enemy featured an illustration of a Sturmabteilung parade and the seven-inch single 'Time Will Tell' by No Remorse displayed a photographic portrait of Hitler. In 1990, the single 'For You' by Public Enemy featured a triskelion (a Celtic symbol consisting of three legs or lines radiating from a centre) while 'Salute!' by Public Enemy featured a Totenkopf (SS death's head symbol) above a photograph of Hitler Youth on the front sleeve.

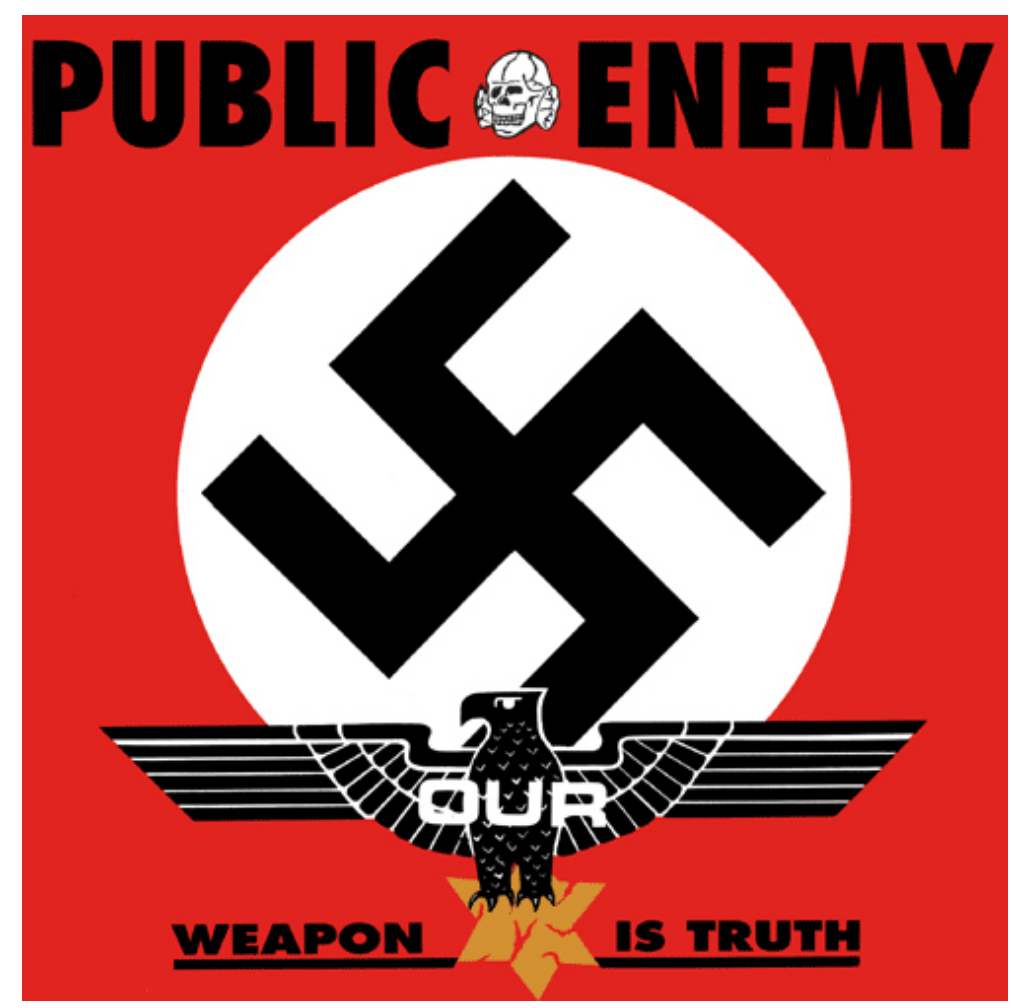

Figure 19 Public Enemy (1991), Our Weapon is Truth, vinyl album, Brest: Rebelles Européens.

\footnotetext{
${ }^{12}$ It is unclear whether the name of Burnley's band bears any relation to the American hip-hop band of the same name. That group broke into the UK top-40 charts in 1987 with the singles 'Rebel Without a Pause' and 'Bring the Noise', and their second album It Takes a Nation of Millions to Hold Us Back (1988) went high in the UK album charts.
} 
In 1991, Public Enemy released one of the most visually brazen sleeves using Nazi iconography. Our Weapon is Truth prominently displayed a swastika in a white circle on red background mimicking the Nazi flag beneath a Totenkopf and above a Parteiadler carrying a crushed Star of David (Figure 19).

To say that the album cover is controversial is an understatement: on the front a fullsize swastika and a stylised Nazi eagle with its claws grasping a fractured Star of David and on the back a photograph of two blonde-haired Aryan children, one of whom has his head stuck in the book The Hoax of the Twentieth Century by Arthur R. Butz, as well as another stylised Nazi eagle with its claws grasping a swastika this time. Little wonder that the cover attracted the attention of the authorities, who caused all kinds of problems for label boss Gaël Bodilis. Vocalist Paul Burnley defended his use of the swastika as follows: 'We are proud of the swastika. It represents the power of our glorious White race and also the great struggle against corruptive elements in Germany in the '30s. Gaël was happy for the cover. If it was a problem for him, we would have changed it. He feels as we do.' (Article in French fanzine One Voice, 1993, cited in Forbes \& Stampton 2015: 437)

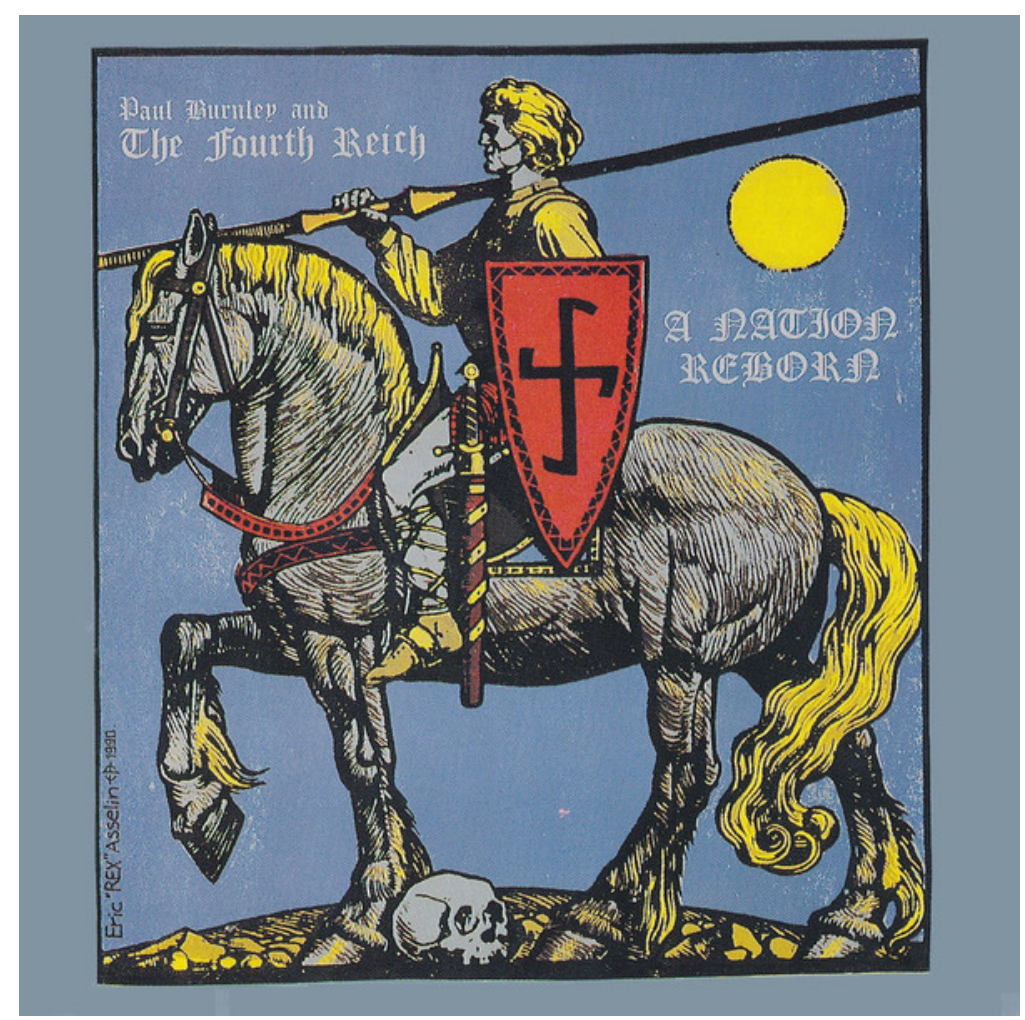

Figure 20 Paul Burnley and the Fourth Reich (1991), A Nation Reborn, vinyl album, Brest: Rebelles Européens. Design by Eric 'Rex' Asselin, based on an original illustration by Georg Sluyterman von Langeweyde. 
In 1991, A Nation Reborn by Paul Burnley and the Fourth Reich featured a fair-haired knight with a swastika on his shield (Figure 20). Although the artwork is signed 'Eric 'Rex' Asselin 1990', the artist's intervention is solely the colouring of an original linocut by Georg von Sluyterman Langeweyde, a member of the Nazi SA whose illustrations were used for Nazi propaganda, as in this benefit postcard for the German Red Cross. During the 1970s, the same illustration had been used on the front sleeve of the album Deutsche Marsche: German Military Marches - Volume 3 by the Oakleaf Collection, which released re-recordings of Third Reich music (McKenzie 2001: 78).13 It is noticeable that the sleeves of Paul Burnley's projects - No Remorse, Public Enemy and Paul Burnley and the Fourth Reich - predominantly exhibit Nazi imagery, more frequently than any other acts, whether through the use of the swastika or other Nazi propaganda images. ${ }^{14}$

From 1987 to 1992, Rebelles Européens released a series of five compilation albums entitled Debout!. The series utilised a standard layout of black and white sleeves with line drawings of soldiers representing chronologically sequenced European armies that had pursued expansionist empires. In addition, in 1989 a compilation album including the participation of the British bands Public Enemy, Lionheart and No Remorse, was released commemorating Adolph Hitler's 100th birthday. The album 100 featured photographs of Hitler Youth parades on the front and back sleeves. In contrast to Rock-O-Rama Records, few albums released by Rebelles Européens fail to exhibit clear neo-fascist symbols on the sleeve.

\footnotetext{
${ }^{13}$ The album After the Fire by Skrewdriver, released on Rock-0-Rama Records in 1988, also reinterpreted an illustration by Georg von Sluyterman.

${ }^{14}$ It is also interesting to note that Paul Burnley and his brother John, drummer for Skrewdriver, had a privileged upbringing and were immersed in the art world. Their father was the Scottish painter John Bellany, who was awarded a CBE in 1994.
} 


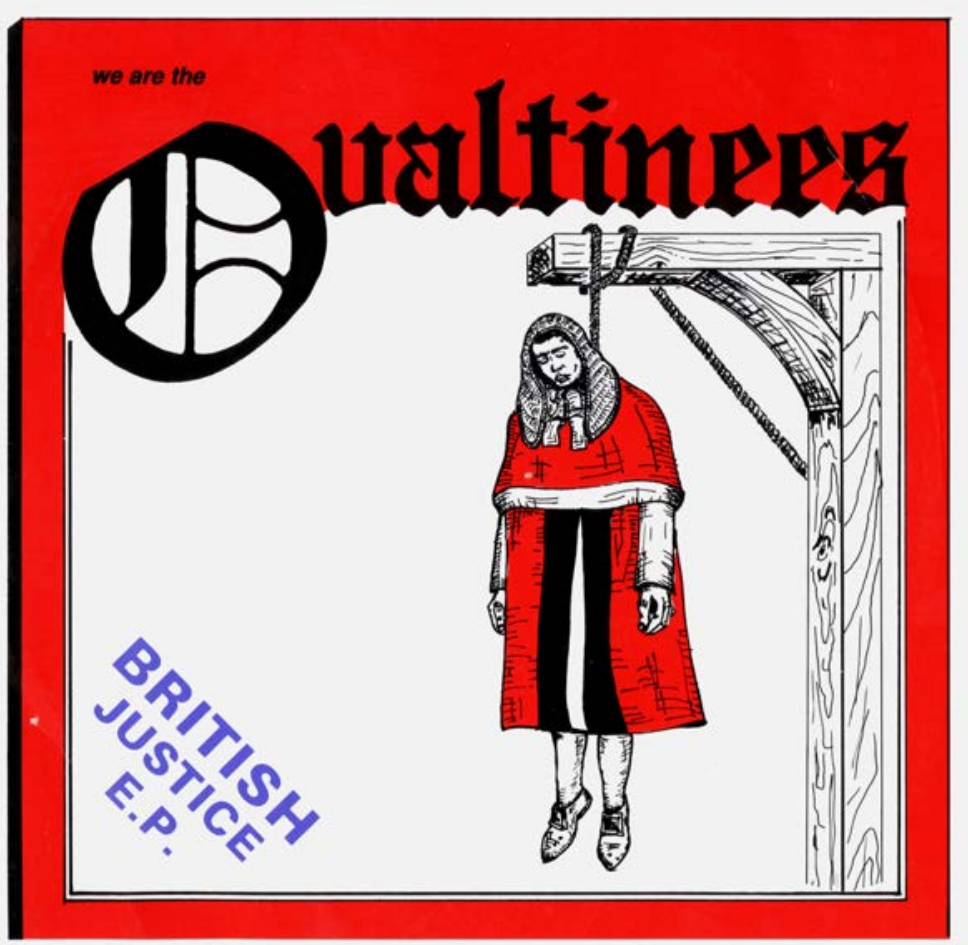

Figure 21 The Ovaltinees (1992), British Justice, vinyl 7" EP, Brest: Rebelles Européens. Design by Binks.

In 1992, a year before a temporary production hiatus at Rebelles Européens, a number of releases report persecution of the scene. Further problems ensued and Rebelles Européens came to an end at around the same time as Rock-O-Rama Records in 1994.

\section{ISD Records}

The music organisation and distributor Blood \& Honour was launched in 1987. It emerged as the result of a collapsing relationship between the White Noise Club - a division of the National Front assigned to music - and the party itself (Blood \& Honour 1994: 2). One of the most visible outputs of the organisation was a magazine that revealed the purpose of the organisation in its title Blood \& Honour: The Independent Voice of Rock Against Communism. ${ }^{15}$ The editorial of an issue of Blood \& Honour dedicated to Ian Stuart and his legacy claims that:

Within a year nearly all Nationalist bands and music fans had joined with Blood \& Honour (the only exception being Skullhead who organised independently from White Noise, but were happy to co-operate with Blood \& Honour) leaving White

\footnotetext{
15 The founding bands involved in the creation of Blood \& Honour were Skrewdriver, Brutal Attack,
} Sudden Impact, No Remorse and Squadron (Lowles \& Silver 1998: 10). 
Noise with a handful of members and bands to cash in on. It wasn't long before the NF deserted their minute but loyal (or stupid) White Noise supporters. (Blood \& Honour 1994: 2)

Blood \& Honour is often identified by the code 28 (the second and eighth letters of the Roman alphabet, B and H). The name derives from the slogan emblazoned on Hitler Youth daggers - Blut und Ehre - reflecting the movement's political affiliation, National Socialism. ${ }^{16}$ However articles in the magazine reveal on several instances the desire to achieve unity within the wider far right and neo-fascist movement; 'We've got the power, we've got the pride, when we get the unity - it's alright' (Blood \& Honour c.1995: 7). Unity is sought both politically; 'patriots, nationalist, third positionists, odinists, etc. are more than welcome at our gigs' (Blood \& Honour 1998: 17).

Ian Stuart died in 1993 in a car accident and Blood \& Honour followed a convoluted path during the transition of power. Ultimately Combat 18 - the armed wing of Blood \& Honour - acquired control over the organisation, particularly through leading activist William 'Wilf' Browning. Despite the radical purpose of creating Blood \& Honour to dissociate the music scene from political parties, after its restructuring the magazine gradually integrated more politics within its format. Eventually it provided political parties with a section to broadcast their activities, including the British National Party, the British Movement, the British Ulster Alliance and even the party that had caused the initial disgruntlement, the National Front.

Combat 18 (C18) ${ }^{17}$ then founded ISD Records, in honour of Ian Stuart Donaldson, in 1994. It was the first neo-fascist label to be established in Britain after the dissolution of White Noise Records six years earlier. Most of the bands, disenchanted with their experience with Rock-O-Rama Records, welcomed the new label, as Bondy from Skullhead proclaimed,

Rock-O-Rama has been ripping off bands for too long. It's a pity it took Ian's death to get ISD going, we could have done with it years ago. National Socialists in control of everything that concerns the band's releases, is like a breath of fresh air. I know, from experience, dealing with ROR was frustrating, if not worse at times. (Blood \& Honour c.1994: 4)

\footnotetext{
16 The name also featured in the title of a 1982 German-American TV mini-series, Blood and Honour: Youth Under Hitler (Blut and Ehre: Jugend Unter Hitler in German), a copy of which Ian Stuart had on video. The miniseries portrayed the growing conflict between a fast-rising member of the Hitler Youth and his resolutely anti-Nazi parents. (see Forbes \& Stampton 2015: 181)

${ }^{17}$ The 18 represents the first and eighth letters of the alphabet - $\mathrm{A}$ and $\mathrm{H}-$ standing for Adolph Hitler.
} 
ISD Records released original material by British bands such as Celtic Warrior, Chingford Attack, No Remorse, Razors Edge, Skrewdriver, Skullhead, Squadron, Violent Storm, Warhammer, Warlord and White Diamond and foreign bands such as Day of the Sword and People Haters (US), Bitfrost (France) and A.D.L. 122 (Italy). Additionally it established a distribution network for material released on other neo-fascist labels.

Control over Combat 18, and subsequently Blood \& Honour and ISD Records, was a constant struggle. From a humble beginning with a limited pressing of $500 \mathrm{CDs}$ for their first release, at its peak ISD records was releasing runs of 5,000 CDs and produced a profit of over $€ 100,000$ between 1994 and 1996 (Lowles \& Silver 1998: 35). Combat 18 was dominated by struggles for power after Stuart's death in 1993, either internally - with control disputed by Charlie Sargent and Browning - and with other organisations and individuals on the neo-fascist scene, leading to direct threats against each other (Lowles 2001; Shaffer 2017). In 1996, in conjunction with Danish Combat 18 leader Thomas Nabaka, Browning organised a terrorist attack. The pair made three letter bombs to be posted to former Olympic swimmer and television presenter Sharron Davies, the London office of Anti-Fascist Action and Brad Hollanby, the guitarist from neo-fascist band Squadron who had fallen out with the leadership, but their plot was foiled (Lowles 2001). Two years later, during internal feuding over control of Combat 18, Chris Castle, an associate of Browning, was murdered by former Combat 18 leader and Blood \& Honour editor Charlie Sargent and Martin Cross, a member of numerous bands including Skrewdriver and Brutal Attack (Blood \& Honour 1998: 13).

The first release by ISD Records was a posthumous album by Skrewdriver, Hail Victory, in 1994. The front sleeve, crudely drawn, presents a masked warrior mounted on a black unicorn in a white mist. It evokes the metaphorical imagery inherited from the Rock-0-Rama Records tradition and continues a trend across other early sleeves of ISD Records, such as Skullhead's album Ragnorok (1995), which featured a Viking boat. The first volume of the ISD series of Blood \& Honour compilations broke this tendency and set ISD Records on a path of explicit graphic outputs, as is to be expected by a confrontational organisation such as Combat 18. The sleeve of Blood \& Honour: Volume 1, released in 1995, displayed a flag with the main characteristics of the Nazi flag - a black symbol on a white circle in a red background - albeit with a broken swastika, fronted by an unidentified militia soldier holding a rifle (Figure 22). 


\section{通lood : 通onour}

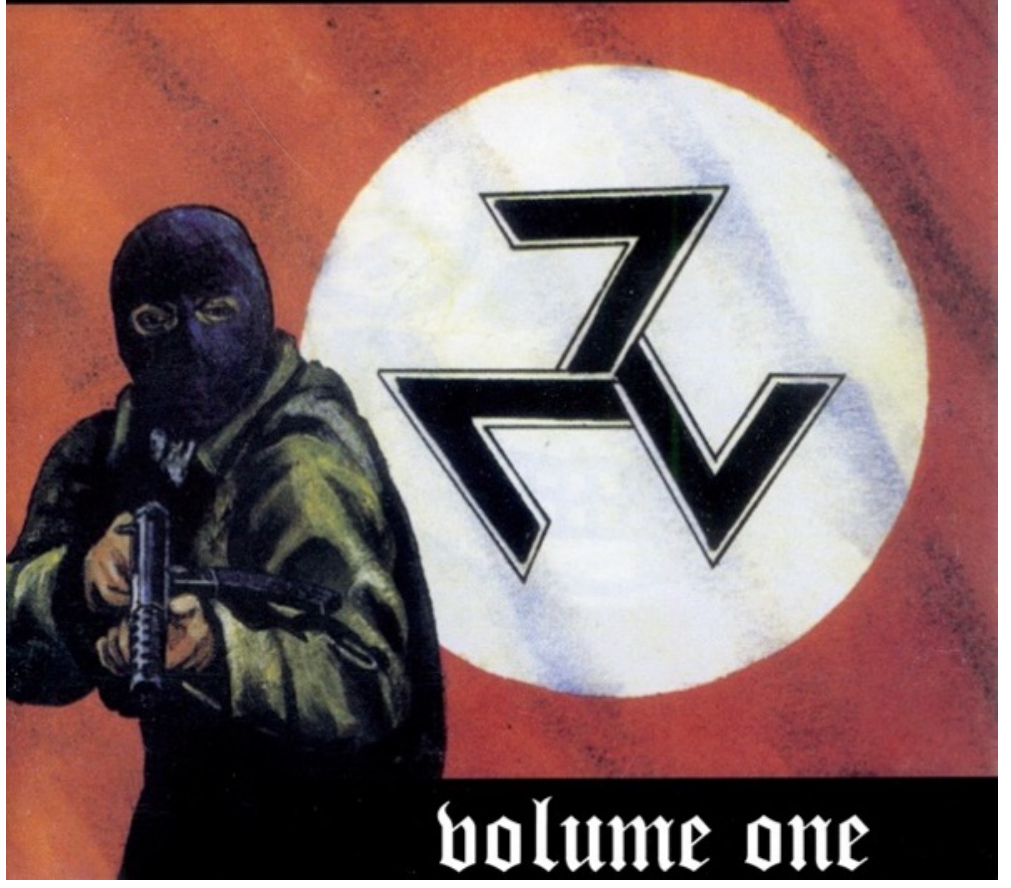

Figure 22 Various Artists (1995), Blood \& Honour: Volume One, cd album, Hillerod: ISD Records.

The series had five volumes. Two subsequent volumes followed the layout established in Blood \& Honour: Volume 1, replacing the symbol used in the flag with the Flash and Circle of the British Union of Fascists on Blood \& Honour: Volume 2 released in 1996, and with a swastika on Blood \& Honour: Volume 5 released in 2005. Blood \& Honour: Volume 3, released in 2000, featured a Totenkopf. The fourth volume was graphically set apart from the rest of the series: Blood \& Honour: Volume 4, released in 2003, portrayed a skinhead - reminiscent of Mick Furbank's illustrations - holding a flag with a Celtic cross in a graveyard. The sleeve presumably acts as a homage to fallen comrades.

In 1996, ISD Records released one of the most controversial albums ever produced by the neofascist scene in Europe, Barbecue in Rostock by No Remorse. By then Paul Burnley, now vilified, was no longer with No Remorse and his place was taken by Jacko, who had been selected by Will Browning. The renewed No Remorse presented an even more extreme stance than the previous line-up (Lowles \& Silver 1998: 42). The album title refers to the xenophobic riots in Rostock in Germany in 1992, which escalated tragically when neo-fascists converged on Rostock and bombarded a house for asylum seekers with petrol bombs. It took four days for the police to control the situation. The front sleeve featured an illustration of a neo-fascist skinhead grilling a kebab containing a Turkish immigrant featuring the stereotyped representation of a big nose. Following widespread condemnation and press attention surrounding the release, ISD Records 
was forced to move its address to Denmark in 1997 to avoid legal prosecution (Blood \& Honour 1997). More broadly, things were changing within far right politics in the United Kingdom. Nick Griffin's successful leadership bid in 1999 led to the modernisation and rebranding of the British National Party and close ties with Combat 18 were severed. While 'neo-nazi skinhead music continued to be a transnational conduit between foreign fascists' (Shaffer 2017: 246), notably through Blood \& Honour in the United Kingdom and the Hammerskins in the US, the BNP sought to pursue a more mainstream political agenda, moving away from the White Power punk and rock scene in the process. ${ }^{18}$

References to Combat 18 are omnipresent in ISD releases on both the back and front sleeves. The back sleeve of the Chingford Attack album Reds Better Run When We're On The Attack (2001) features the slogan 'We are Blood \& Honour, we are Combat 18, we are Chingford Attack!' while the front displays the British Bulldog that had been drawn in the late 1970s for Bulldog: Paper of the National Young Front with the NF replaced by the Combat 18 logo. Further sleeves featured the Combat 18 logo on the front. The album Deutschland by No Remorse (2006) features a Parteiadler carrying the Combat 18 logo, while Valhalla's Warriors by Warhammer (2000) displays a photograph of a live show with the flag of England in the background alongside the symbols C18, 14 - representing the 14 words $^{19}$ - and 88 - code for Heil Hitler - next to a German World War II flag, the iron cross and the swastika. Following threats of legal action and further splits, ISD Records currently operates from a base in Texas in the United States.

\section{From Fantasy Art to Paramilitary Propaganda}

This article charts the history of four individual record labels closely associated with far right punk scenes in the United Kingdom between the late 1970s and the early twenty-first century. It extends previous studies to analyse the visual strategies employed by key figures in the evolution of an overtly neo-nazi scene that offered support to paramilitary organisations and eventually became embroiled in extreme violence and terrorism. While early examples of far right punk record covers produced under the agreement with Rock-O-Rama employed ambiguous visual metaphors and fantasy images alluding to a mythical Aryan past, this visual strategy was superseded by the emergence of a more covert form of visual communication that utilized symbols employing coded meanings to demonstrate a commitment to the neo-nazi cause.

\footnotetext{
${ }^{18}$ In 2005 the party even established a new music label, Great White Records, to support traditional folk music with far right lyrical content and promoted a number of concerts and festivals dedicated to a more pastoral, family-friendly form of musical entertainment.

1914 words is a reference to the popular white supremacist slogan 'We must secure the existence of our people and a future for white children'.
} 
By the early 1980s, punk's original propensity to shock had merged into a more explicit form of visual messaging. Anti-war and anti-vivisection ideologies in particular were adopted across anarcho-punk and hardcore scenes, with hard-hitting graphic images adorning record sleeves, flyers and fanzine pages. Visual tropes on British Rock Against Communism records produced under license with Rock-O-Rama Records include representations of patriotism and nationalism through national symbols; struggle for the restoration and preservation of the Teutonic myth, through the usage of Norse imagery and mythology; and an appeal for alliance and endurance through subcultural representations and claimed persecution. Labels created purposefully for the dissemination of neo-fascist rock - such as Rebelles Européens and ISD Records - were notably less cautious in their use of explicit imagery, even going so far as to openly display the swastika and other neo-nazi symbols on record covers and marketing material. At the same time, the evolution of independent labels dedicated to the far right cause enabled a level of autonomy that further encouraged explicit communication strategies. While the search for self-determination inspired many bands to set up their own labels in the late 1970s and 1980s, that same spirit of independence also facilitated a darker period in the history of punk and post-punk.

\section{References}

Bain, Peter and Paul Shaw (eds.) (1998), Blackletter: Type and National Identity. New York: Princeton Architectural Press.

Barthes, Roland (1977) [1961], 'The Photographic Message', in Heath, Stephen (ed.) (1977), Image, Music, Text. Translated from the French by Stephen Heath, London: Fontana Press. Berger, George (2009), The Story of Crass, Oakland, CA: PM Press.

Bestley, Russ and Alex Ogg (2012), The Art of Punk, London: Omnibus Press.

Bestley, Russ (ed.) (2013), Where Have All the Bootboys Gone? Skinhead Style and Graphic Subcultures, London: London College of Communication.

Blood \& Honour: The Independent Voice of Rock Against Communism, 1987-1994, London: Blood \& Honour. Issues 1 (1987a), 2 (1987b), 3 (1988a), 4 (1988b), 5 (1988c), 6 (1988d), 7 (1988e), 8 (c.1989a), 9 (c.1989b), 10 (1990), 12 (c.1991), 13 (1992a), 14 (1992b), 17 (1994).

Blood \& Honour (c.1988), White Skins, White Pride, London: Blood \& Honour.

Bulldog: Paper of the Young National Front, 1979-1984, London: National Front. Issues 13 (1979a),14 (1979b), 15 (c.1979), 16 (c.1980a), 17 (c.1980b), 18 (c.1980c), 21 (c.1980d), 25 (1981), 26 (1982a), 27 (1982b), 28 (1982c), 31 (1983a), 34 (1983b), 35 (1983c), 38 (1984a), 39 (1984b).

Chingford Attack (2001), Reds Better Run When We're On The Attack, CD album, London: ISD Records. 
Cloonan, Martin (1996), Banned!: Censorship of Popular Music in Britain, 1967-92, Aldershot: Arena.

Copsey, Nigel and Richardson, John E. (eds.) (2015), Cultures of Post-War British Fascism, London: Routledge.

Copsey, Nigel and Worley, Matthew (eds.) (2017), Tomorrow Belongs to Us: The British Far Right Since 1967, London: Routledge.

Collins, Matthew and Gerry Gable (eds.) (2003), Signs of Hate Ilford: Searchlight Information Services.

Cotter, John M. (1999), 'Sounds of Hate: White Power Rock and Roll and the Neo-Nazi Skinhead Subculture', Terrorism and Political Violence 11,2, pp. 111-140.

Crass (1978), The Feeding of the Five Thousand, vinyl album, London: Crass Records.

Duncombe, Stephen and Max Tremblay (eds.) (2011), White Riot: Punk and the Politics of Race. New York: Verso.

Forbes, Robert and Stampton, Eddie (2015), The White Nationalist Skinhead Movement: UK \& USA 1979-1993, Port Townsend: Feral House.

Futrell, Robert, Pete Simi and Simon Gottschalk (2006), 'Understanding Music in Movements: The White Power Music Scene', The Sociological Quarterly, 47, pp. 275-304.

Gaunt, S. (1979), British News 46, Leeds, January.

Glasper, Ian (2006), The Day the Country Died: A History of Anarcho Punk 1980 to 1984, London: Cherry Red Records.

Green, Mark (2007) Ian Stuart Donaldson: Memories, Chemnitz: PC Records.

Hebdige, Dick (1982), 'This is England! And they don't live here', in Knight, Nick (1982),

Skinhead, London: Omnibus Press, pp.26-36.

Knight, Nick (1982), Skinhead, London: Omnibus.

Last Chance (c.1991), issue 8, fanzine. (1992), issue 12, fanzine.

Lowles, Nick (2001), White Riot: The Violent Story of Combat 18, Bury: Milo Books.

Lowles, Nick and Steve Silver (eds.) (1998), White Noise: Inside the International Nazi Skinhead Scene, London: Searchlight.

Marshall, George (1994), Spirit of '69: A Skinhead Bible, London: ST Publishing, Second edition. Morrison, Eddy (2002), Memoirs of a Street Soldier, self-published.

McKenzie, Stuart C. (2001), Collecting Third Reich Recordings, Shropshire: Ulric Publishing. Newport, Ian (1981), We Are NF, London: Newport Fotos.

The Ovaltinees (1992), British Justice, EP, Brest: Rebelles Européens.

Pachnicke, Peter \& Honnef, Klaus (1992), John Heartfield, New York: Harry N. Abrams.

Pearce, Joe (1987), Skrewdriver: The First Ten Years, London: Skrewdriver Services. Available 
from: www.bloodandhonourworldwide.co.uk/isd/bio/firsttenyears.html (accessed 11 April 2020).

Raposo, Ana (2012), 30 Years of Agit-prop: The Representation of 'Extreme' Politics in Punk and Post-Punk Music Graphics in the United Kingdom from 1978 to 2008, PhD thesis, University of the Arts London.

Raposo, Ana and Sabin, Roger (2017), 'New visual identities for British neo-fascist rock (19821987): White Noise, 'Vikings' and the cult of Skrewdriver', in Copsey, Nigel and Worley, Matthew (eds.) (2017), Tomorrow Belongs to Us: The British Far Right Since 1967, London: Routledge, pp. 132-149.

Riot 77 (c.2000), 'Interview with Mensi', in Green, M. (2007), Ian Stuart Donaldson: Memories, Chemnitz: PC Records.

Robb, John (2006), Punk Rock: An Oral History, London: Ebury Press.

Rock-O-Rama Records (2008) Dokumentation gegen Rock-O-Rama, Bruhl: Rock-O-Rama Records.

(2008a), Rock-O-Rama Records... Nach 30 jahren lieder aus der punk-ära: teil 1, Bruhl: Rock-O-Rama Records.

Rock-O-Rama Records (2008b), Rock-O-Rama Records... Nach 30 jahren lieder aus der RAC-ära: teil 2, Bruhl: Rock-0-Rama Records.

Sabin, Roger (1999), 'I Won't Let the Dago By: Rethinking Punk and Racism', in Punk Rock: So What?, edited by Roger Sabin, London: Routledge, pp. 199-218.

Shaffer, Ryan (2017), Music, Youth and International Links in Post-War British Fascism: The Transformation of Extremism, London: Palgrave Macmillan.

Shekhovtsov, Anton and Paul Jackson (eds.) (2012), White Power Music: Scenes of Extreme-Right Cultural Resistance, Ilford and Northampton: Searchlight Magazine Ltd and the Radicalism and New Media Research Group.

Silver, Steve (1998), 'Blood and Honour 1987-1992', in White Noise: Inside the International Nazi Skinhead Scene, edited by Nick Lowles and Steve Silver, London: Searchlight, pp. 9-27. Skrewdriver (1977a), 'You're So Dumb', 7" single, London: Chiswick Records. (1977b), 'Anti-Social', 7" single, London: Chiswick Records. (1984), Hail The New Dawn, vinyl album, Bruhl: Rock-O-Rama Records. (1985), Blood \& Honour, vinyl album, Bruhl: Rock-O-Rama Records. (1987), White Rider, vinyl album, Bruhl: Rock-O-Rama Records. (2000), Rockumentary 1977 to 1993: From Punk to Patriotism, CD, Sweden: Midgard Records.

Skullhead (1991), A Cry of Pain, vinyl album, Köln: United Records.

The Truth at Last (1985), issue 4, fanzine. 
(1987), issue 10, fanzine.

Thurlow, Richard (2006), Fascism in Britain: From Oswald Mosley's Blackshirts to the National Front, London: I.B. Tauris.

Vague, Tom (2013), 'Flashbacks of a Bootboy', in R. Bestley (ed.), Where Have All the Bootboys Gone? Skinhead Style and Graphic Subcultures, London: London College of Communication, p. 11. Weiner, Nathaniel (2018), “Put on Your Boots and Harrington!”: The ordinariness of 1970s UK punk dress', Punk \& Post-Punk, 7:2, pp.181-202.

White Noise (1986), issue 1, London: White Noise Club (1986a), issue 2, London: White Noise Club (1987), issue 3, London: White Noise Club (1987a), issue 4, London: White Noise Club (1987b), issue 5, London: White Noise Club (1988), issue 7, London: White Noise Club

Worley, Matthew (2012), 'Shot by Both Sides: Punk, Politics and the End of "Consensus"', Contemporary British History 26.3, pp. 333-354.

(2014), “'Hey little rich boy, take a good look at me”: Punk, class and British Oi!', Punk \& Post-Punk 3:1, pp. 5-20. (2017), No Future: Punk, Politics and British Youth Culture, 1976-1984, Cambridge: Cambridge University Press. Worley, Matthew and Copsey, Nigel (2017), 'White youth: The far right, punk and British youth culture, 1977-87', in Copsey, Nigel and Worley, Matthew (eds.) (2017), Tomorrow Belongs to Us: The British Far Right Since 1967, London: Routledge, pp. 113-131. 